IZA DP No. 7358

Trade and Labor Reallocation with Heterogeneous

Enforcement of Labor Regulations

Rita K. Almeida

Jennifer P. Poole

April 2013 


\title{
Trade and Labor Reallocation with Heterogeneous Enforcement of Labor Regulations
}

\author{
Rita K. Almeida \\ World Bank and IZA \\ Jennifer P. Poole \\ University of California, Santa Cruz
}

Discussion Paper No. 7358

April 2013

IZA

P.O. Box 7240

53072 Bonn

Germany

Phone: +49-228-3894-0

Fax: +49-228-3894-180

E-mail: iza@iza.org

\begin{abstract}
Any opinions expressed here are those of the author(s) and not those of IZA. Research published in this series may include views on policy, but the institute itself takes no institutional policy positions. The IZA research network is committed to the IZA Guiding Principles of Research Integrity.

The Institute for the Study of Labor (IZA) in Bonn is a local and virtual international research center and a place of communication between science, politics and business. IZA is an independent nonprofit organization supported by Deutsche Post Foundation. The center is associated with the University of Bonn and offers a stimulating research environment through its international network, workshops and conferences, data service, project support, research visits and doctoral program. IZA engages in (i) original and internationally competitive research in all fields of labor economics, (ii) development of policy concepts, and (iii) dissemination of research results and concepts to the interested public.
\end{abstract}

IZA Discussion Papers often represent preliminary work and are circulated to encourage discussion. Citation of such a paper should account for its provisional character. A revised version may be available directly from the author. 


\section{ABSTRACT}

\section{Trade and Labor Reallocation with Heterogeneous Enforcement of Labor Regulations}

This paper revisits the question of how trade openness affects labor market outcomes in a developing country setting. We explore the fact that plants face varying degrees of exposure to global markets and to the enforcement of labor market regulations, and rely on Brazil's currency crisis in 1999 as an exogenous source of variation in access to foreign markets. Using administrative data on employers matched to their employees and on the enforcement of labor regulations at the city level over Brazil's main crisis period, we document that the way trade openness affects labor market outcomes for plants and workers depends on the stringency of de facto labor market regulations. In particular, we show for Brazil, a country with strict labor market regulations, that after a trade shock, plants facing stricter enforcement of the labor law decrease job creation and increase job destruction by more than plants facing looser enforcement. Consistent with our predictions, this effect is strongest among small, labor-intensive, non-exporting plants, for which labor regulations are most binding. These findings are consistent with the hypothesis that, in the context of strict de jure labor market regulations, increased enforcement limits the plant-level productivity gains associated with increased trade openness. Therefore, increasing the flexibility of de jure regulations may allow for broader access to the gains from trade.

JEL Classification: F16, J6, J8

Keywords: globalization, enforcement, labor market regulations, employer-employee data

Corresponding author:

Jennifer P. Poole

Department of Economics

University of California, Santa Cruz

437 Engineering 2

Santa Cruz, CA 95064

USA

E-mail: jpoole@ucsc.edu

\footnotetext{
* Our special thanks to Paulo Furtado de Castro for help with the RAIS and SECEX data and to the Department of Economics and Academic Computing Services at the University of California, San Diego for assistance with data access. We also thank the Brazilian Ministry of Labor for providing data on the enforcement of labor regulations and important information about the process of enforcement, especially Edgar Brandão, Sandra Brandão, and Marcelo Campos. For helpful comments and suggestions, we are grateful to JaeBin Ahn, David Atkin, Pedro Carneiro, Kiko Corseuil, Anca Cristea, Lisandra Flach, Penny Goldberg, Jesko Hentschel, Brian Kovak, Kevin Milligan, Devashish Mitra, Marc Muendler, Lourenço Paz, Giovanni Peri, Martin Rama, Priya Ranjan, Dave Richardson, Jose Antonio Rodriguez-Lopez, Nick Sly, Petia Topalova, Eric Verhoogen, and to workshop participants at Claremont McKenna College, the Federal Reserve Bank of San Francisco, Syracuse University, UC Irvine, UC San Diego, Yale University, and various conferences. Financial support from the UCSC Academic Senate Committee on Research is acknowledged. Aaron Cole and Kun Li provided excellent research assistance.
} 


\section{Introduction}

A key argument in favor of liberalizing trade relations is that factors can reallocate to more efficient uses, allowing for enhanced productivity, income growth, and consumer welfare (Pavcnik 2002; Feyrer 2009; Broda and Weinstein 2006). Early studies in many developing countries, however, found little impact of trade liberalization on plant-level employment and wages (Currie and Harrison 1997; Feliciano 2001). More recent work offers evidence of slow labor market adjustment to trade reform (Menezes-Filho and Muendler 2011). A potential explanation for these findings are restrictive labor market regulations, which inhibit the reallocation of workers, limiting the extent to which plants can benefit from increased openness (Freund and Bolaky 2008; Kaplan 2009; Hsieh and Klenow 2009).

In this paper, we revisit the question of the impact of trade liberalization on labor reallocation in a developing country by exploring the fact that plants vary in the degree of exposure to global markets and that de facto labor regulations are heterogeneous within countries. We rely on detailed administrative data from Brazil covering the country's currency devaluation episode. Our main reduced-form specification relates exogenous industry-specific exchange rate shocks to plant and worker outcomes over time, differentially for plants located in distinct labor market regulatory environments. Our findings show that more stringent de facto regulations reinforce the contractionary labor market effects of trade openness for small, labor-intensive, non-exporting plants. Overall, domestic plants in strictly-enforced areas increase job destruction and decrease job creation by more than otherwise identical domestic plants in weakly-enforced areas, as they face increases in the costs of employing workers. We also demonstrate that strict labor market institutions limit the possibility for plant-level productivity and profitability gains associated with trade openness.

From a policy standpoint, our work offers an understanding of labor turnover in an increasingly globalized world. The trade-off between job security, on the one hand, and productivity and growth, on the other hand, is one of the most prominent public policy debates worldwide. The long-term gains from an open and flexible economy may be accompanied by short-term costs for workers in terms of unemployment. Our work shows that policies designed to protect workers may actually further reduce employment as costs to firms increase. Therefore, increasing the flexibility of de jure regulations will stimulate job creation and offer broader access to the gains from trade. 
We contribute to a growing body of work in several ways. First, the micro-data available for Brazil are rich and appropriate to study the effects of trade liberalization on labor turnover. We exploit a matched employer-employee database covering the formal-sector labor force, in combination with information on the plant's exposure to global markets. Importantly, the data allow us to analyze employment at the plant level, and also to trace the movement of workers across different employers in response to a trade shock. Furthermore, it permits the decomposition of labor turnover into changes along the extensive margin (the accession and separation of workers) and along the intensive margin (hours worked and temporary contracts).

Our empirical strategy exploits the ability to match workers to their employers, which is critical as pointed out by the recent evidence on the sorting effect of globalization. ${ }^{1}$ For instance, as in the model described in Helpman, Itskhoki, and Redding (2010), when there are complementarities between plant productivity and worker ability, plants have an incentive to screen for workers below a given ability level. Higher productivity exporters screen to a higher ability threshold and will thus have a workforce of higher average ability than non-exporters. ${ }^{2}$ Because globalization increases plant selection into exporting as in Melitz (2003) and the incentives to screen for high-quality matches, it is important to account for heterogeneity in the quality of the worker-plant match in determining the effects of globalization on labor market outcomes (Woodcock 2011; Krishna, Poole, and Senses 2011). In our setting, an otherwise identical worker may have a higher probability of separation from (or a lower probability of accession to) a high productivity plant than from (and to) a low productivity plant, when such worker-plant production complementarities exist. This diversity offers disparate predictions for the effects of trade liberalization on worker turnover at exporting (high productivity) and non-exporting (low productivity) plants. Our reduced-form estimation builds on the existing literature in this dimension. Notably, our preferred specification uses information on worker-level labor market outcomes, separately for exporting and domestic plants, and allows for the possibility of worker sorting.

While we are not the first authors to investigate the impact of trade by the plant's mode of globalization (e.g., Amiti and Davis (2012)), we are not aware of any paper allowing for

\footnotetext{
${ }^{1}$ Verhoogen (2008) documents a skill-upgrading in Mexican exporting plants after the 1994 peso devaluation. Bustos (2011) looks at the Brazilian reduction in tariffs as part of the Mercosur regional free trade agreement and finds that Argentinean plants above the median size upgrade skills, while plants below the median size downgrade skills.

${ }^{2}$ Changes in the skill composition of the workforce at exporters relative to non-exporters are also present in a number of other recent trade models (see, for example, Yeaple (2005)).
} 
globalization to impact plants differently depending on their exposure to labor market regulatory enforcement. Brazil has one of the most restrictive labor market regulatory frameworks in the world (Botero, et al 2004; Almeida and Carneiro 2012). ${ }^{3}$ However, the size of the informal labor force suggests that enforcement is weak in some areas, hinting at a gap between the laws stated on the books (de jure regulations) and their effective implementation (de facto regulations). Therefore, contrary to previous studies which rely on cross-country or across-state variation in existing de jure labor regulations (e.g., Besley and Burgess (2004) and Autor, Kerr, and Kugler (2007)), we explore the fact that Brazilian employers are exposed to varying degrees of de facto labor regulations, via Ministry of Labor inspections. Especially in a developing country context where enforcement is not homogeneous, we argue exploring time series and within-country variation in regulatory enforcement offers a better measure of a plant's true flexibility in adjusting labor to shocks than looking at variations in de jure regulations. ${ }^{4}$ We thus investigate the differential impact of globalization on worker turnover among otherwise identical plants and workers facing different de facto enforcement of the labor law. ${ }^{5}$

Finally, in contrast to most of the literature investigating the impact of trade liberalization on the real economy using potentially endogenous tariff changes ${ }^{6}$, we explore the Brazilian currency's strong devaluation in January 1999 as a large and unanticipated exogenous shock to both employers and workers. ${ }^{7}$ Following Goldberg (2004), we construct trade-weighted industry-specific real exchange rates in order to capture changes in industry competitiveness over time. The economy-wide real exchange rate depreciated 32\% from 1996 to 2001, with a 23\% drop occurring between December 1998 and January 1999 alone (see Figure 3.1; Muendler (2003)). However,

${ }^{3}$ There is an extensive literature for developing countries analyzing the relationship between labor market regulations and labor market outcomes (e.g., Kugler (1999), Kugler and Kugler (2009), Ahsan and Pages (2009), Petrin and Sivadasan (forthcoming), and several other studies cited in Heckman and Pages (2004)).

${ }^{4}$ To date, few papers have explored both within-country and time series measures of enforcement. Notable exceptions include Caballero, Cowan, Engel, and Micco (2013) and Almeida and Carneiro (2012).

${ }^{5}$ Currie and Harrison (1997) rule out labor market regulations as an explanation for their insignificant finding of the effects of trade reform on employment levels, and suggest that despite formal labor market barriers there is little enforcement which leaves regulations ineffective. Unlike Currie and Harrison (1997), our city-level data on Ministry of Labor inspections allow us to capture exactly this variation in withincountry compliance with labor market regulations.

${ }^{6}$ Political economy factors in tariff formation and adjustment have been noted by a number of authors. See, for example, Olarreaga and Soloaga (1998) for the case of Brazil's regional free trade area, Mercosur. In fact, as protectionist pressures grew in the aftermath of the introduction of a new currency in 1994, average tariffs marginally increase beginning in 1995. See Section 2.2 for further discussion.

7 Other papers using currency shocks as exogenous sources of variation to investigate international trade relationships include Verhoogen (2008), who uses Mexico's 1994 peso devaluation to explore the relationship between trade and inequality, and Brambilla, Lederman, and Porto (2012), who use Brazil's currency crisis as a shock to Argentinean exporters. 
though all industries suffered exchange rate declines over this time period, some endured more severe shocks than others, as measured by trade-weighted real exchange rates. We rely on this industry-level variation in real exchange rates over time to exogenously identify the effect of Brazil's increased globalization on employment and labor turnover at the plant and worker level.

To summarize, we analyze the effect of trade liberalization on labor reallocation within Brazil. We explore across industry and over time variation in real exchange rates in order to capture changes in industry competitiveness, in combination with city and time variation in the enforcement of labor market regulations, facing exporters and non-exporters. An important concern relates to the exogeneity of the variation in the enforcement of labor regulations across cities. At any given point in time, enforcement of labor regulations at the city level is not likely to be randomly distributed. On the one hand, enforcement may be stronger in cities with higher violations of the law. On the other hand, cities with better institutions could have stricter enforcement. Although it is unclear how these patterns may impact worker reallocation, a potential bias may still exist. To minimize this concern, we note that our empirical methodology follows the program evaluation literature and relates exogenous real exchange rate changes to plant and worker outcomes over time, differentially for plants located in variable labor market regulatory environments. Our main coefficient of interest is the differential effect of changing enforcement on plants that, all else constant, are exposed to different exogenous industry-specific trade shocks. Therefore, our reduced-form specification relates annual changes in the probability of inspection in a given city and annual changes in industry-specific real exchange rates, with annual changes in labor market outcomes. We run this specification separately for exporting and non-exporting plants.

One could still question the exogeneity of changes in enforcement at the city level. To the extent that these changes correlate with changes in labor market outcomes, our estimates for the effects of enforcement may be biased. We emphasize, however, that our focus is on the interaction between exogenous changes in industry-specific real exchange rates and changes in the degree of regulatory enforcement, as is customary in the program evaluation literature. For our main coefficient of interest to be biased, it must be that plants in industries exposed to greater depreciations and in cities exposed to greater de facto enforcement also have systematically different labor turnover, for some unobserved reasons. One possibility is that industries are regionally-concentrated, such that the industries experiencing the most severe depreciations are located in the cities experiencing the greatest increases in enforcement (i.e., growing cities that may also have more dynamic labor 
markets). Our reduced-form estimation includes state-specific year dummies, which we argue helps to correct for some of this bias. We also include interactions between pre-determined city conditions and the real exchange rate changes in order to control for the possibility that cityspecific trends may be driving the differences in labor turnover we find. Finally, we show that our main results are robust to the inclusion of the lagged value of enforcement.

We begin our analysis at the plant-level, investigating the differential impact of trade openness on plant size for plants located in heavily-inspected cities relative to plants located in weakly-inspected cities. We then consider a more disaggregated worker-level analysis. This allows us to decompose how plants adjust labor in response to currency devaluations and how enforcement influences these adjustments-along the extensive margin (hiring and firing) or along the intensive margin (changes in hours worked or between full-time and temporary contracts). Meanwhile, our workerlevel analysis helps to address the possibility of worker sorting in the labor reallocation process.

We now briefly discuss the main empirical predictions in our reduced-form model. With a devaluation of the Brazilian currency (the real), imports into Brazil become more expensive, improving the competitiveness and enhancing the profitability of Brazilian plants selling in the domestic market. To the extent that profits and employment growth are correlated at the plant level, a currency depreciation is expected to increase employment for the average plant in the country. ${ }^{8}$ The same depreciation differentially improves conditions for exporters, as Brazil's trading partners need fewer currency units to purchase Brazilian goods. We expect this enhanced foreign market access to differentially increase employment at Brazil's exporting plants relative to plants producing only for the domestic market.9

Our hypothesis relies on the extent to which labor regulations "bite"; that is, whether regulations are enforced. An increase in the enforcement of labor market regulations through more labor inspections is expected to directly impact the compliance with labor regulations through the hiring

\footnotetext{
8 Revenga (1992) uses the sharp appreciation of the U.S. dollar during the early 1980s to demonstrate significant employment reductions for import-competing industries. Ribeiro, et al (2004) consider the case of Brazil, documenting the importance of the exchange rate for job creation. Interestingly, Burgess and Knetter (1998) evaluate employment responses to exchange rate shocks at the industry-level across the G-7 countries, and argue that country-level differences in the response to the exchange rate shock may be attributable to variation in labor market regulations.

9 Goldberg and Tracy (2003) demonstrate that the employment declines associated with a U.S. dollar appreciation grow stronger as industries increase in export orientation.
} 
and firing of formal labor. ${ }^{10}$ However, the direction of the effect of enforcement on employment is ambiguous. On the one hand, stricter enforcement of labor regulations raises the cost of formal workers. As such, plants facing stricter enforcement will have increased difficulties in adjusting labor. On the other hand, the stricter enforcement of labor regulations also increases job quality, in terms of compliance with mandated benefits for the worker. For this reason, we may find increases in employment in more heavily-enforced cities, as formal employment becomes a more attractive option and formal work registration increases.

In this paper, we focus on the differential impact of openness on labor market outcomes across plants located in cities with varying degrees of regulatory enforcement. Our main results are consistent with the view that the extent to which trade affects labor market outcomes depends on the de facto degree of stringency of the labor regulations faced by plants. In particular, plants facing stricter enforcement of the labor laws increase employment by less than plants facing fewer inspections with the expansionary trade shock. Moreover, conditional on several time-varying worker, plant, city, and sector characteristics, as well as controls for worker sorting, we note that openness is associated with a decrease in the probability of firing at expanding exporters, and a decrease in the probability of hiring at relatively contracting domestically-oriented plants, as is predicted by new heterogeneous firm trade models. The results suggest that enforcement mainly influences labor adjustment along the extensive margin, but also has some effect on the intensive margin as captured by differential decreases in the probability of a full-time contract. We find little adjustment along the intensive margin as captured by hours worked. We note also that our findings are concentrated among small, labor-intensive, non-exporting plants for which labor regulations are likely to be most restrictive, as well as among younger workers who are more likely to be labor market "outsiders".

The magnitudes of our estimates seem to be plausible. Evaluating the effect on workers and plants located in municipalities at the mean level of inspections, a 10 percentage point depreciation of the

\footnotetext{
${ }^{10}$ Cardoso and Lage (2007) show that inspections are primarily linked to stricter enforcement of mandatory severance payments, mandated health and safety regulations, and to the worker's formal registration. Bertola, Boeri, and Cazes (2000) suggest that differences in enforcement across countries, related for example to the efficiency of a country's legal system, are as or even more important, than differences in de jure regulations. For example, Caballero, Cowan, Engel, and Micco (2013) explore a panel of 60 countries around the world and find that labor regulations have adverse effects on job turnover and plants' speed of adjustment to shocks, but only in countries with a strong rule of law and government efficiency (taken as measures of enforcement of regulations). However, as with many cross-country studies, the limited time series variation in labor regulations and measures of enforcement poses challenges for identification.
} 
real increases job match creation at exporting plants by $2.3 \%$ and decreases job creation at nonexporters by $3.6 \%$, as is predicted by heterogeneous firm models of international trade. Meanwhile, the impact for domestic plants varies depending on the level of enforcement the plant faces-for domestic plants located in municipalities at the $10^{\text {th }}$ percentile of inspections, a 10 percentage point depreciation of the real decreases the probability of hire by only $2.5 \%$, while workers matched with domestic plants located in municipalities in the $90^{\text {th }}$ percentile of inspections experience a decrease in job match creation of around 4.9\%. Similarly, a 10 percentage point depreciation decreases the probability of job destruction at domestic plants located in cities at the $10^{\text {th }}$ percentile of inspections by $0.5 \%$, while the same exchange rate shock increases the firing probability at similar domestic plants in cities at the $90^{\text {th }}$ percentile of inspections by $2.3 \%$.

Our results strongly suggest that more stringent de facto regulations limit job creation with enhanced trade openness. Overall, small, labor-intensive, non-exporters separate from more workers and hire fewer workers with increased enforcement of regulations. We show that this increased enforcement of labor regulations is also associated with lower plant-level productivity, as proxied by plant-level average wages. Our plant-level results on employment also corroborate this idea.

In addition to the work cited above, our paper relates with a number of different literatures. First, our research is closely linked to a growing body of structural models linking trade and labor market policies, such as firing costs. In the model presented by Coşar, Guner, and Tybout (2011), tariff liberalizations increase firm-level job turnover, and reductions in firing costs reinforce the impact of globalization further increasing job turnover. Kambourov (2009) presents a model in which liberalizing trade in a restricted labor market environment is associated with slower inter-sectoral labor market reallocation, lower output, and reduced productivity. Fajgelbaum (2012) notes that labor market frictions, which increase the costs of hiring workers, reduce firm growth and productivity, inducing a negative relationship between labor market rigidities and openness across countries. We see these structural papers as complementary to our reduced-form framework designed to identify the causal implications of trade openness on labor reallocation in the presence of a complete set of labor market regulations.

Second, our research is related to a set of empirical papers on product market liberalizations in different labor market environments. Aghion, Burgess, Redding, and Zilibotti (2008) show that 
India's deregulation of the License Raj (control over entry and production in the manufacturing industry) led to differential rates of growth across industries located in states with pro-employer labor market institutions relative to industries located in states with pro-worker labor institutions. Hasan, Mitra, and Ramaswamy (2007) also distinguish India's states by the extent of labor market restrictions, and analyze the impact of India's 1991 trade reform on labor demand. The authors find supportive evidence for the interaction of trade reform and labor regulations; that is, the impact of trade reform on labor demand is larger in states with more flexible labor institutions. Using the same data, Topalova (2010) demonstrates that India's trade liberalization negatively impacted poverty and per capita expenditures predominantly in states with less flexible labor markets. Also relevant to our study is Freund and Bolaky (2008) who argue that trade can only improve living standards in flexible economies. In particular, their findings on hiring and firing costs suggest that the positive effects of openness are reduced when labor regulations are excessive. Similarly, Eslava, Haltiwanger, Kugler, and Kugler (2010) consider the case of Colombia's pro-market reforms of the 1990s. The authors find that allowing for frictionless factor adjustment would lead to substantial improvements in efficiency over the reform period. The benefit of linked employer-employee data allows us to move beyond the industry level and state level, to compute individual-level accessions and separations, as well as to incorporate worker and plant heterogeneity. Moreover, as we previously mention, exploiting variation in de facto labor regulations offers a more complete measure of labor market flexibility than variation in de jure labor regulations alone.

The paper proceeds as follows. In the next section, we provide background information on the 1988 Brazilian Constitutional reform, which established the current labor market regulatory framework in Brazil, the recent evolution in the enforcement of these labor laws conducted by the Ministry of Labor, and the main features of Brazil's recent globalization. In Section 3, we outline our main data sources and offer some simple descriptive statistics. Section 4 discusses the conceptual framework behind our main empirical strategy and proposes a simple difference-in-difference reduced-form specification for the empirical work. In Section 5, we present our main findings. Section 5 also offers evidence for the robustness of our main results, as well as evidence on the heterogeneity of our main findings. Finally, Section 5 discusses the aggregate implications of the enforcement of labor regulations on plant-level productivity. We conclude in Section 6 by highlighting the main policy implications. 


\section{Policy Background}

The late 1980s to the early 2000s marked a period of substantial market-oriented reform in Brazil. Of particular relevance to our work are the establishment of a new Constitution in 1988, which offered increased employment protections for workers, the liberalizing trade policy reforms beginning in 1987, and the implementation of a new currency in 1994. Subsequently, the currency experienced a severe and unanticipated devaluation in January 1999. Each of these policy changes may have contributed to changing labor costs and labor reallocation.

\subsection{Labor market regulations within Brazil}

The 1988 Constitutional reform The Brazilian Federal Constitution of 1988 imposed high labor costs to plants and was very favorable to workers. First, it reduced the maximum weekly working period from 48 to 44 hours. Second, it increased the overtime wage premium from $20 \%$ to $50 \%$ of the regular wage. Third, the maximum number of hours for a continuous work shift dropped from 8 to 6 hours. Fourth, maternity leave increased from 3 to 4 months. Finally, it increased one month's vacation time pay from 1 to $4 / 3$ of a monthly wage.

Following the 1988 changes in the labor code, the cost of labor to employers increased. First, the employer's payroll contribution increased from $18 \%$ to $20 \%$. Second, the penalty on the plant for dismissing the worker without cause increased from $10 \%$ to $40 \%$ of the total contributions to the severance fund, Fundo de Garantia do Tempo de Serviço (FGTS). ${ }^{11}$ Employers in Brazil must also give advance notice to workers in order to terminate employment. During this interim period, workers are granted up to two hours per day (25\% of a regular working day) to search for a new job. ${ }^{12}$

Enforcement of labor regulations These de jure labor regulations are effective throughout the country. However, as the Ministry of Labor is charged with enforcing compliance with labor regulations, there is significant heterogeneity both within country and over time in terms of how binding is the law. ${ }^{13}$ Given the geographic scope of the country, enforcement is first decentralized to

\footnotetext{
${ }^{11}$ If the worker is dismissed without justification (with the exception of workers on a probationary period), the plant is fined and has to pay the worker $40 \%$ of the FGTS contributions.

${ }^{12}$ Some plants voluntarily choose to grant workers the full monthly wage without requiring work. Barros and Corseuil (2004) find that there are large productivity losses during this period.

${ }^{13}$ A comprehensive explanation of the enforcement of the labor regulation system and its importance in Brazil is given in Cardoso and Lage (2007).
} 
the state level with the main labor offices (delegacias) located in the state capital. Enforcement is then further decentralized to the local level within each state, depending on the size of the state. For example, in 2001 the state of São Paulo had 24 local labor offices (subdelegacias) while smaller states had only the one office coinciding with the delegacia in the state capital.

Throughout the late 1990s and early 2000s, labor inspections became more frequent as the large public deficit led the Brazilian government to search for alternative ways to collect tax revenue. ${ }^{14}$ We note time variation in the location of local labor offices as new subdelegacias open over time. For instance, in 1996 in addition to the delegacia in the state capital, the state of Bahia had 6 subdelegacias. By 2001, Bahia had 8 subdelegacias. Because of this, the average distance to the nearest Ministry of Labor office decreased by about 5\% between 1996 and 2001. In addition, the average number of inspections in the manufacturing sector per municipality increased from 13.2 in 1996 to 14.3 in 2001. As inspectors reached out with increased intensity, the median number of inspections also increased, suggesting a leftward shift of the distribution of inspections across municipalities.

Most of the inspections and subsequent fines for infractions in Brazil are to ensure plants' compliance with workers' formal registration in the Ministry of Labor, contributions to the severance pay fund (FGTS), minimum wages, and maximum working lengths. Evasion of one of these dimensions accounted for more than $40 \%$ of all fines issued in 2001 . The monetary amount of the fines is economically significant and may be issued per worker or it may be indexed to the plant's size. For example, in 2001 values, a plant is fined 216 reais (or approximately $\$ 100$ ) for each worker without a carteira de trabalho, formal work authorization. Considering that, at 2001 prices, the federal minimum wage was 222 reais, non-compliance with worker registration is non-trivial, implying a penalty of approximately one monthly wage per worker.

Plants weigh the costs and benefits of complying with this strict labor regulation. They decide whether to hire formally, informally, or formally but without fully complying with specific features of the labor code (e.g., avoiding the provision of specific mandated benefits, such as health and safety conditions, or avoiding payments to social security). The expected cost of evading the law is a

\footnotetext{
${ }^{14}$ An inspection can be triggered either by a random plant audit, or by a report (often anonymous) of noncompliance with the law. Workers, unions, the public prosecutor's office, or even the police can make reports. In practice, almost all of the targeted plants are formal plants because it is difficult to visit a plant that is not registered, since there are no records of its activity.
} 
function of the monetary value of the penalties (fines and loss of reputation) and of the probability of being caught. In turn, the probability of being caught depends on the plant's characteristics (such as size, globalization status, and legal status) and on the degree of enforcement of regulation in the city where the plant is located. ${ }^{15}$

\subsection{Brazil's globalization}

Policy reforms The second half of the 20th century in Brazil was characterized by tight import substitution industrialization policies designed to protect the domestic manufacturing sector from foreign competition. Beyond high tariff rates, substantial non-tariff barriers characterized Brazilian trade policy during this time period. The latter half of the 1980s and the beginning of the 1990s, however, witnessed sweeping changes in Brazilian trade policy. This occurred in two phases. First, average ad valorem final goods tariff rates fell from 58\% in 1987 to $32 \%$ in 1989. These reforms had little impact on import competition however, as non-tariff barriers remained highly restrictive. Second, between 1990 and 1993, the federal government abolished all remaining non-tariff barriers inherited from the import substitution era and announced a schedule for the reduction of nominal tariffs over the next four years (Moreira and Correa 1998). Effective rates of protection fell by over 70\% in just four years-from approximately 48\%, on average, in 1990 to 14\%, on average, in 1994 (Kume, Piani, and Souza 2003).

In 1994, after decades of high inflation and several unsuccessful stabilization attempts, the Brazilian government succeeded with a macroeconomic stabilization plan (Plano Real), designed to help correct a large fiscal deficit and lastingly end hyperinflation. The new currency, the real, was pegged to the U.S. dollar, and began at parity on July 1, 1994. Officially, the real was set to a crawling peg which permitted the currency to depreciate at a controlled rate against the U.S. dollar. However, as the country's persistent effort to control inflation paid off, the real exchange rate actually appreciated in its first months. In response, the government partially reversed trade reforms in 1995 after manufacturing industries lost competitiveness due to the real's appreciation. ${ }^{16}$

\footnotetext{
${ }^{15}$ As inspectors face a performance-based pay scheme, they often look for cases where the penalty is likely to be large. As such, there is a strong correlation between the size of the firm, as a proxy for the visibility of the firm, and the number of inspections (Cardoso and Lage 2007).

${ }^{16}$ Average ad valorem tariffs climbed slightly in subsequent years-from an average of $12.2 \%$ in 1994 to an average of $14.4 \%$ in 2001 .
} 
Currency crisis Despite efforts to control public spending and raise tax revenues, Brazil's fiscal deficits remained high and continued to grow. Meanwhile, persistent current account deficits placed significant pressure on the pegged exchange rate and government reserves, leading investors to withdraw funds from Brazil. In response to the financial crises in Asia in 1997 and Russia in 1998, the authorities raised interest rates to encourage domestic savings and investment. However, as debt service obligations increased, investor panic persisted. Dollar reserves fell from approximately $\$ 58$ billion in 1996 to $\$ 43$ billion in 1998. In mid-January 1999, capital outflows accelerated further when the Governor of the State of Minas Gerais declared a moratorium on the state's debt payments to the national government, triggering the government's announcement of the end of the crawling peg, allowing the real to float against the U.S. dollar (Gruben and Kiser 1999). Overnight, the nominal exchange rate devalued by $9 \%$ against the U.S. dollar, and by the end of the month, the real had depreciated by $25 \%$ (see Figure 3.1).

\section{Data}

Our main data are administrative records from Brazil for formal sector workers linked to their employers. We match these data by the plant's municipality with city-level information on the enforcement of labor market regulations, by the plant's sector with information on industry-specific real exchange rates, and by the employer tax identifier to information on exposure to global markets. The sample period for analysis covers Brazil's main currency crisis period, between 1996 and 2001. This exogenous shock to plant and worker outcomes allows us to uncover the differential impact of increased exposure to trade on labor reallocation depending on the degree to which plants face regulatory enforcement and access to foreign markets.

Matched employer-employee administrative data We use data collected by the Brazilian Labor Ministry, which requires by law that all registered establishments report on their formal workforce in each year. ${ }^{17}$ This information has been collected in the administrative records Relação Anual de

\footnotetext{
17 For this reason, our analysis is restricted to the effect of trade liberalization on formal labor reallocation. It is plausible, however, that in cities with weaker enforcement and hence more flexible labor adjustment, plants may be more likely to make adjustments along the informal margin. Therefore, our findings on formal labor adjustment do not capture total labor adjustment. It is not clear, however, how the results would change. Goldberg and Pavcnik (2003), Paz (2012), and Menezes-Filho and Muendler (2011) find mixed results on the impact of trade liberalization on the informal sector in Brazil. Also, to the extent that enforcement increases the cost of labor, we may note shifts away from labor (both formal and informal) towards capital.
} 
Informações Sociais (RAIS) since 1986. For our analysis, we use data from RAIS for the years 1996 through 2001, when we also have complementary information on regulatory enforcement, exchange rates, and the employer's globalization status.

The main benefit of the RAIS database is that both plants and workers are uniquely identified allowing us to trace workers over time and across different plants. The data also include the industry and municipality of each plant. ${ }^{18}$ Other relevant variables of interest include the worker's month of accession to and the month of separation from the job, weekly hours worked, and the type of employment contract (temporary versus permanent), as well as detailed information on the worker's human capital, including occupation, education, tenure at the plant, gender, and age. We define a worker as hired to employer $j$ during year $t$ if RAIS reports a non-missing value for the month of accession. We define a worker as fired from employer $j$ during year $t$ if RAIS reports the worker no longer employed at firm $j$ on December 31 of year $t$.

We restrict observations in RAIS as follows. We draw a 1\% random sample of the complete list of workers ever to appear in the national records and retrieve their complete formal sector employment history. We include only manufacturing sector (CNAE 2-digit codes 15-37) workers in private-sector jobs.

Enforcement data We explore administrative city-level data on the enforcement of labor regulations, also collected by the Brazilian Ministry of Labor. Data for the number of inspector visits are available by city and 1-digit sector for the years 1996, 1998, 2000, and 2002. We use the information on visits by inspectors to manufacturing plants only. For our analysis, we interpolate average values for the missing years and match the enforcement data to the RAIS data by the plant's municipal location. This information identifies plants and workers facing varying degrees of regulatory enforcement.

We proxy the degree of regulatory enforcement with the intensity of labor inspections at the city level. In particular, our main measure of enforcement, designed to capture the probability of a visit by labor inspectors to plants within a city, is the logarithm of the number of labor inspections at the city level (plus one) per 100 plants in the city based on RAIS. This scaled measure of inspections

18 The industrial classification available in RAIS is the 4-digit National Classification of Economic Activities (CNAE). 
helps to control for important size differences across cities (i.e., that São Paulo has many inspections, but also many plants to inspect). Moreover, the impact of such a measure will reflect the direct effect of inspections, as well as plants' perceived threat of inspections (even in the absence of plant-level inspections) based on inspections at neighboring plants.

Table 3.1 reports the nationwide increase in enforcement of labor regulations between 1996 and 2001. The proportion of cities with at least 1 manufacturing inspection rose from 33\% in 1996 to $52 \%$ in 2001. This corresponds to an increase in the average number of inspections across cities, most notably between 1998 and 2000, when the average number of inspections increased by 15\%. As the number of inspections at the city level is correlated with the size of the city (i.e., population, labor force, and number of plants), our preferred measure documents the number of inspections per 100 registered plants as is reported in column (3). The data report increases in the number of inspections per 100 plants, as inspectors intensify the enforcement process to reach additional plants, workers, and cities. The same patterns hold for the number of inspections per 10,000 workers com carteira in column (4).

We also note significant within-country variation in the intensity of enforcement across cities in Brazil, as is depicted by the average number of inspections per 100 plants in each city in Figure 3.2. The left panel illustrates the intensity of enforcement per Brazilian city in 1998, with darker shades portraying higher numbers. The right panel depicts the same statistic two years later in the year 2000. We remark on the variation across municipalities and over time. First, we observe the darkest areas of the map in the high-income Southern and Southeastern regions of the country. We also notice a darkening of the map between 1998 and 2000 as enforcement spreads to further parts of the country. Figure 3.3 offers a clearer picture of the across city and over time variation in regulatory enforcement by focusing in on a single state, Mato Grosso.

We rely on these differential changes in enforcement across cities over time in our main empirical analysis. For this reason, it is important to understand the determinants of changes in enforcement at the city level. To this end, Table 3.2 reports coefficients from an ordinary least squares regression in first differences for the set of Brazilian municipalities in 2001 for which we have historical information from Brazil's Institute for Applied Economic Research (IPEA) @Cidades database. The dependent variable is the change in enforcement between 1996 and 2001, where enforcement is defined as the logarithm of the number of inspections in the city (plus one) per 100 plants. In 
column (1), we relate changes in enforcement to lagged changes (1991-1996) in the city's industrial composition (agricultural GDP, manufacturing GDP, and services GDP) and population. Column (2) also includes lagged changes in the city's urbanization rate, while column (3) also includes lagged changes in the city's poverty rate. The results report that cities with growing manufacturing and services sectors and increasing urbanization and poverty rates have larger increases in enforcement. Our main reduced-form estimation will include interactions between these predetermined city conditions and the industry-specific real exchange rate changes in order to control for the possibility that city-specific trends may be driving the differences in labor turnover we find.

Industry-specific exchange rates We construct trade-weighted industry-specific real exchange rates based on bilateral real exchange rate data from the International Monetary Fund and bilateral trade flows by commodity made available by the National Bureau of Economic Research (Feenstra, et al 2004). ${ }^{19}$ We match the industry-specific real exchange rates to the RAIS data by the plant's industrial classification, in order to identify plants and workers in industries with differential globalization experiences. ${ }^{20}$

As was previously noted, Brazil's aggregate real exchange rate devalued in January 1999, increasing the relative price of Brazilian imports. However, the aggregate exchange rate may be less effective at capturing true changes in industry competitiveness, induced by changes in specific bilateral exchange rates, if particular trading partners are of particular importance for particular industries. That is, movements in the dollar/real, peso/real, and euro/real exchange rates may have different implications for different industries, depending on the industry's trade with the U.S., Argentina, and Europe, respectively. Therefore, following Goldberg (2004), we calculate the trade-weighted real exchange rate as follows:

$$
\operatorname{trer}_{t}^{k}=\sum_{c}\left(\left(.5 * \frac{X_{t-1}^{k c}}{\sum_{c} X_{t-1}^{k c}}+.5 * \frac{M_{t-1}^{k c}}{\sum_{c} M_{t-1}^{k c}}\right) * \operatorname{rer}_{t}^{c}\right)
$$

\footnotetext{
19 Trade flows are organized by Standard Industrial Trade Classification (SITC) codes. We match the 4-digit SITC revision 2 codes to the 4-digit CNAE codes available in RAIS using publicly available concordances (http://www.econ.ucsd.edu/muendler/html/brazil.html\#brazsec).

${ }^{20}$ As we discuss in Section 2.2, average tariff rates were relatively flat over our sample period. Variations in the real exchange rate, therefore, provide a more realistic measure of changes in trade openness during our sample period.
} 
where $t$ indexes time, $k$ indexes industry, and $c$ indexes country, such that the bilateral real exchange rate, $\operatorname{rer}_{t}^{c}$, denoted in terms of foreign currency units per real, is weighted by industry-specific and time-varying export shares $\left(\frac{X_{t-1}^{k c}}{\sum_{c} X_{t-1}^{k c}}\right)$ and import shares $\left(\frac{M_{t-1}^{k c}}{\sum_{c} M_{t-1}^{k c}}\right)$. Following Campa and Goldberg (2001), we lag the trade shares one period to avoid issues of endogeneity between trade and the exchange rate.

A decrease in the value of this index implies a real depreciation of the Brazilian real in tradeweighted terms for industry $k$. Across all industries, the average index decreased from 0.97 in 1996 to 0.62 in 2001, with the most dramatic drop of roughly 30\% occurring between 1998 and 1999. As Figure 3.4 illustrates in the left and right panels, respectively, there is also substantial heterogeneity across industries in both the level of and annual changes in the real exchange rate. Though the mean exchange rate is valued at 0.66 in 1999 in the aftermath of the crisis, the manufacture of other food products has a substantially lower trade-weighted real exchange rate at 0.54 , while the tradeweighted real exchange rate in the industry which manufactures strings, cables, and other cords is far higher at 0.80. Similarly, while all sectors experienced sharp exchange rate declines between 1998 and 1999, some suffered more than others. Non-ferrous metal manufacturing endured the steepest annual depreciation of 40 percentage points, while sugar manufacturing faced a mere 16 percentage point decline.

Exposure to global markets Finally, we investigate information on the firm's degree of global engagement, as captured by total export sales. We rely on complementary data from the Brazilian Customs Office (SECEX) to create a single indicator for the firm's globalization status. Information on firm-level export transactions is available from SECEX, which records all legally-registered firms in Brazil with at least one export transaction in a given year.

We denote exporters to be those firms that exported a positive dollar amount at any point during the 1996 to 2001 time period. This time-invariant indicator is designed to minimize potential endogeneity concerns surrounding the export decision post-devaluation. In robustness checks, we also compare similarly-sized plants, which we argue helps to minimize any possible selection bias associated with the plant's globalization status. Also, in unreported results, we categorize plants based on the industry's import penetration as an alternative measure of globalization.

\subsection{Descriptive statistics}


We report detailed descriptive statistics in Table 3.3. Column (1) reports statistics for our final sample of formal-sector manufacturing workers, as well as the plants, cities, and industries in which they work. Column (2) reports summary statistics for the sample of exporting plants, while column (3) reports statistics for domestic plants. The final sample has 322,614 worker-plant-year observations, with 109,086 workers employed in 61,462 plants, covering 2,829 municipalities and 240 industries throughout the sample period of 1996 to 2001.

Approximately $33 \%$ of manufacturing workers were hired to a new employer during our sample period, while $29 \%$ were separated from their employer. The data report that only $2 \%$ of workers are employed with temporary contracts. Across employers, workers averaged 43.5 hours per week. The average age of a worker is 32 years. The majority of the manufacturing labor force has less than a high school education, while about $26 \%$ have at least a high school education, and only $7 \%$ have a tertiary education. Roughly a third of the manufacturing labor force is employed in skilled blue collar professions, such as machine operators. Another $24 \%$ are in white collar professions $-7 \%$ in secretarial and sales positions and $17 \%$ in professional, managerial, and technical positions. Eleven percent of the formal manufacturing sector is employed in unskilled blue collar jobs, most often found in the construction and service sectors. The average plant employs 99 workers, and pays an average annual wage of 2,909 reais (an average monthly wage of 242 reais). The average municipality in our sample faces approximately 42 inspections during the 1996 to 2001 sample period. ${ }^{21}$ The average industry has a trade-weighted real exchange rate index of 0.81 and employs over 17,000 workers, of which about 1 in every 5 are unionized.

Of the 61,462 plants, roughly one-fifth are exporters. However, these 13,921 plants represent over half of the total number of observations, largely because exporting plants employ more workers on average (at 233 workers as compared to 40 workers for domestic plants). Our data reports that accession rates are lower at exporters than at non-exporters-27\% as compared to $39 \%$, respectively. We also find that separation rates are lower at exporting plants for our sample of workers. Our RAIS matched data sample report the common finding in the literature that, on average, exporters are more skill-intensive and pay higher wages (e.g., Bernard and Jensen (1995)).

${ }^{21}$ This number stands in contrast to the average number of inspections across all Brazilian municipalities (see Table 3.1). Our 1\% random sample covers only registered firms which are, on average, larger. Therefore, this is to be expected, as these firms are naturally more exposed to enforcement than smaller firms (Cardoso and Lage 2007). 
Almost $40 \%$ of the manufacturing labor force at exporters is high-skilled, as defined by those workers with at least a high school education, while by comparison about $25 \%$ of the workforce is high-skilled at plants serving the domestic market. The average annual wage paid by exporting plants is 4,791 reais, as compared to 2,337 reais at domestic plants. Exporters are only represented in about half of the 2,829 municipalities covered by our formal sector data. ${ }^{22}$ Combined with their greater visibility due to the higher total employment numbers, the data indicate that on average the municipalities in which exporters are located are more heavily enforced than those in which domestic plants are located. On average, exporting plants face 68 manufacturing inspections while domestic plants face, on average, 45 inspections. By contrast, exporters and non-exporters are represented across almost all industries in Brazil. For this reason, we see little variation across plant-type in the industry average trade-weighted real exchange rate, employment, or unionization rates.

\section{Empirical Model}

Our goal in this paper is to uncover how trade openness affects labor market reallocation. We consider the devaluation of the real in 1999 as the main exogenous trade shock and argue that a similar trade shock impacts plants differentially based on their exposure to the enforcement of labor regulations and their mode of globalization. We begin with the following framework in mind:

$y_{j k t}=\beta_{1} Z_{j t}+\beta_{2} S_{k t}+\varphi_{j}+\delta_{s t}+\varepsilon_{j t}$

where $j$ indexes the plant, $k$ indexes the plant's industry, and $t$ indexes time. We relate plant-level outcomes $\left(y_{j k t}\right)$, such as total plant employment, to time-varying, plant characteristics $\left(Z_{j t}\right)$ such as average worker tenure at the plant, and the age, gender, educational, and occupational composition of the plant, and time-varying, industry characteristics $\left(S_{k t}\right)$ such as the unionization rate, industry employment, average worker tenure in the industry, and the age, gender, educational, and occupational composition of the industry. The specification also includes plant fixed effects $\left(\varphi_{j}\right)$ to capture time-invariant factors, such as the plant's unobserved underlying productivity, technology, or management style, which may influence both a plant's selection into exporting and plant-level

22 See Aguayo-Tellez, Muendler, and Poole (2010) for further information on the spatial distribution of exporting plants. 
labor market adjustment, and state-specific year dummies $\left(\delta_{s t}\right)$ to control for the average effect on labor turnover of Brazil's many policy reforms over this time period.

Importantly, among the time-varying, industry-specific characteristics is the trade-weighted industry-specific real exchange rate $\left(T R E R_{k t}\right)$ which serves as an exogenous shock to trade openness. Our basic argument is based on the fact that when the real depreciates, the price of goods typically imported into Brazil will rise, improving the competitiveness and increasing profits of Brazilian plants. To the extent that plant profits and employment growth are correlated, we expect that a devaluation of the Brazilian real will increase employment for the average plant.

Table 4.1, intended to motivate the remainder of the paper, provides baseline evidence to this effect. The first column reports results from the estimation of equation (1) where the dependent variable is the logarithm of plant employment. Consistent with the literature (e.g., Revenga (1992)), a depreciation of the trade-weighted real exchange rate (decrease in $T R E R_{k t}$ by our measure) is associated with increases in employment for the average plant.

Equation (1), however, considers only the industry-time shock of the exchange rate devaluation. Brazil's large informal sector suggests significant evasion of Ministry of Labor regulations. The implications of increased trade openness, via a real exchange rate depreciation, for formal labor turnover depend on the degree to which plants are exposed to labor market regulatory enforcement. We hypothesize that two identical plants will respond differently to changes in trade openness depending on the de facto regulations they face. For this reason, we adapt equation (1) as follows:

$y_{j m k t}=\gamma_{1} T R E R_{k t} * E N F_{m t}+\gamma_{2} T R E R_{k t}+\gamma_{3} E N F_{m t}+\beta_{1} Z_{j t}+\beta_{2} S_{k t}+\varphi_{j}+\delta_{s t}+\varepsilon_{j m t}$

where $m$ now indexes the city (munícipio). $E N F_{m t}$ represents time-varying, municipality-level enforcement of labor regulations, as captured by Ministry of Labor inspections. All other variables are as previously defined. $\gamma_{1}$, our main coefficient of interest, captures the differential impact of a trade shock on plants in strictly-enforced municipalities relative to weakly-enforced municipalities. In response to an expansionary trade shock, such as Brazil's currency devaluation, plants wish to expand employment $\left(\gamma_{2}<0\right)$. However, plants in heavily-inspected cities may be differentially restricted from adjusting labor $\left(\gamma_{1}>0\right)$-as the cost of a formal worker increases, strictly-enforced 
plants will increase employment by less than weakly-enforced plants—or may adjust formal labor by relatively more $\left(\gamma_{1}<0\right)$, as formal work registrations increase.

We take this ambiguous prediction to the data in column (2) of Table 4.1. Enforcement is measured by the logarithm of the number of inspections at the city level (plus one). As in column (1), the exogenous real exchange rate depreciation increases plant-level employment. Consistent with the findings in Almeida and Carneiro (2012), the unreported coefficients on city-level enforcement demonstrate that increases in regulatory enforcement at the city level tend to decrease formal plant size, suggesting that increases in the cost of formal workers dominate any potential impact from increased compliance with mandated benefits and formal work registrations.

In this paper, we are interested in the interaction term reflecting the differential impact of globalization on plants located in strictly-enforced municipalities $\left(\gamma_{1}\right)$. Our results confirm that plants in heavily-inspected cities are restricted from expanding employment with a depreciation of the currency relative to plants in less-inspected cities.

An important concern relates to the exogeneity of the variation in the enforcement of labor regulations across cities. In particular, enforcement may be stricter in cities where violations of the labor laws are more frequent or in cities where institutions are more developed. Moreover, enforcement may be stronger for more visible (i.e., larger and more globalized) plants. As violations of labor laws, better institutions, and plant size and type are likely also correlated with labor market outcomes, to minimize this concern, in column (3) of Table 4.1, we adjust our main enforcement variable to control for the size of the city. Specifically, our preferred enforcement variable moving forward characterizes inspections per 100 plants in the city. This accounts for the fact that large cities have many inspections, but also many plants to be inspected. In addition, in the absence of plant-level information on inspections, our analysis aims to capture the probability that a plant is inspected, allowing for the direct effect of inspections, as well as the indirect effect of a neighboring plant's inspections.

One could still question the exogeneity of changes in enforcement at the city level. To the extent that these changes correlate with changes in labor market outcomes, our estimates for the effects of enforcement may be biased. We emphasize, however, that our focus is on the interaction between exogenous changes in industry-specific real exchange rates and changes in the degree of regulatory 
enforcement, as is customary in the program evaluation literature. For our main coefficient of interest to be biased, it must be that plants in industries exposed to greater depreciations and in cities exposed to greater de facto enforcement also have systematically different labor turnover, for some unobserved reasons. One possibility is that industries are regionally-concentrated, such that the industries experiencing the most severe depreciations are located in the cities experiencing the greatest increases in enforcement (i.e., growing cities that may also have more dynamic labor markets). We note that equation (2) includes state-specific year dummies, which we argue helps to correct for some of this bias.

Based on the results in column (3) of Table 4.1, evaluated at the $10^{\text {th }}$ percentile of inspections, a 10 percentage point depreciation increases employment by $1.8 \%$, while the same devaluation increases employment by only $1.2 \%$ at plants located in cities at the $90^{\text {th }}$ percentile of inspections. These plant-level results highlight our main predictions-that strict labor market institutions limit plants' labor adjustment in response to shocks.

\subsection{Worker-level employment transitions}

When facing a trade shock, expanding plants can adjust along the extensive margin by increasing hiring, decreasing firing, or both, as well as along the intensive margin by increasing the hours worked for existing employees or switching from temporary to permanent contracts. Enforcement also influences adjustment along each of these margins. In order to better understand these mechanisms, our main reduced-form equation focuses on a worker-level analysis. In particular, we augment equation (2) as follows:

$$
\begin{aligned}
y_{i j t}= & \gamma_{1} T_{R E R_{k t}} * E N F_{m t}+\gamma_{2} T R E R_{k t}+\gamma_{3} E N F_{m t} \\
& +\beta_{1} Z_{j t}+\beta_{2} S_{k t}+\beta_{3} X_{i t}+\pi_{i j}+\delta_{s t}+\varepsilon_{i j t}
\end{aligned}
$$

where $i$ indexes the worker and $y_{i j t}$ represents worker-level labor market outcomes, such as employment transitions and hours worked per week. We characterize employment transitions with three variables: an indicator variable that takes the value one if a match between worker $i$ and plant $j$ is created at time $t$ (i.e., if there is a plant-year accession), an indicator variable that takes the value one if a match between worker $i$ and plant $j$ is destroyed at time $t$ (i.e., if there is a plant-year separation), and an indicator variable that takes the value one when worker $i$ is employed with a 
full-time contract in plant $j$ at time $t$. All other variables are defined as previously discussed. $X_{i t}$ are time-varying worker-level characteristics (such as the worker's tenure at the plant in months, the worker's age (and age squared), education ${ }^{23}$, and occupation ${ }^{24}$ ) and $\pi_{i j}$ is a worker-plant (timeinvariant) match effect.

We argue that time-invariant worker-plant match effects are important because when worker-plant production complementarities exist (as in new trade models), high productivity plants will screen for high ability workers. This may lead to the sorting of high ability workers into high productivity plants. ${ }^{25}$ In our setting, this implies that following a trade liberalization, otherwise identical workers may have a higher probability of separation from (or a lower probability of accession to) a high productivity plant than from (and to) a low productivity plant. For this reason, we replace the plant fixed effects from equation (2) with worker-plant match-specific fixed effects $\left(\pi_{i j}\right)$, which allow for time-invariant, unobservable match quality (associated with the potential for worker sorting) in the labor reallocation process. ${ }^{26}$

As previously noted, concerns about the endogeneity of regulatory enforcement are minimized as equation (3) relates changes over time in the enforcement of labor market regulations to labor market outcomes. However, as is documented in Table 3.2, cities with growing manufacturing and services sectors and increasing urbanization and poverty rates have larger increases in enforcement. Our main specification, therefore further adapts equation (3) to include interactions between these pre-determined city conditions and the real exchange rate shock in order to control for the determinants of city-level changes in enforcement, as follows:

$$
\begin{aligned}
y_{i j t}= & \gamma_{1} T_{R E R} * E N F_{m t}+\gamma_{2} T_{R E R}+\gamma_{3} E N F_{m t} \\
& +\beta_{1} Z_{j t}+\beta_{2} S_{k t}+\beta_{3} X_{i t}+\beta_{4} T R E R_{k t} * C_{m}+\pi_{i j}+\delta_{s t}+\varepsilon_{i j t}
\end{aligned}
$$

${ }^{23}$ Education enters as two dummy variables: completed high school and more than high school. Less than high school is the omitted category.

24 Occupation enters as three dummy variables: skilled blue collar profession, unskilled white collar profession, and skilled white collar profession. Unskilled blue collar profession is the omitted category.

${ }^{25}$ Krishna, Poole, and Senses (2011) document the importance of worker-firm complementarity in the labor reallocation process post-liberalization using matched employer-employee data for Brazil. Their results, controlling for the non-random assignment of workers to firms, suggests a strong bias in plant-level analyses, as exporters differentially increase match quality relative to non-exporters post-liberalization.

${ }^{26}$ As neither the plant nor the worker vary within a match, the match-specific effects also control for timeinvariant, unobservable plant heterogeneity and time-invariant, unobservable worker heterogeneity. 
where $C_{m}$ are pre-determined city conditions such as industrial composition (agricultural GDP, manufacturing GDP, and services GDP), population, urbanization, and poverty. We interact these city conditions with the trade-weighted real exchange rate to control for differential city-specific trends. All other variables are as previously defined.

The specification in equation (4) relates exogenous changes in industry-specific real exchange rates with match-specific outcomes, between 1996 and 2001, differentially for worker-plant matches in strictly-enforced areas. In other words, we explore a difference-in-difference methodology to identify the effects of openness on labor turnover. The main coefficient of interest in equation (4) is $\gamma_{1}$, which captures the differential effect of stricter enforcement for workers employed in plants exposed to varying real exchange rate changes.

In addition, we argue that the implications of a real exchange rate devaluation are heterogeneous across plant types and therefore, consider equation (4) separately for exporting and domesticallyoriented plants. Our prior is that openness allows plants best placed to compete abroad to expand and those in import-competing industries to relatively contract. We hypothesize that the expansionary effect (increase in hiring, decrease in firing, increase in hours, and increase in fulltime contracts) of the exchange rate shock $\left(\gamma_{2}\right)$ will be larger for exporting plants than for plants serving only the domestic market, as foreign market access improves.

As in the plant-level analysis, the theoretical predictions for $\gamma_{1}$ are ambiguous. On the one hand, the stricter enforcement of labor regulations raises the cost of formal workers. As such, plants facing strict enforcement are predicted to relatively decrease hiring, relatively increase firing, relatively decrease hours, and relatively decrease full-time contracts. On the other hand, the stricter enforcement of labor regulations also increases job quality, in terms of compliance with mandated benefits for the worker. For this reason, we might find evidence of increases in turnover in more heavily-enforced cities, as formal employment becomes a more attractive option and formal work registration increases. We empirically test these ambiguities given our strong predictions on the impact of trade openness on job creation and job destruction for exporters relative to nonexporters.

Moreover, we further hypothesize that labor market regulations on formal employment are less binding for exporting firms, and thus expect the effects of regulatory enforcement to be less 
important for plants exposed to global markets. This hypothesis has foundations in the literature. Cardoso and Lage (2007) argue that the integration of firms in international trade and the need to comply with international quality standards implicitly force firms to comply with labor regulations. This is reinforced in Harrison and Scorse (2003), who report that exporters and foreign firms in Indonesia are more likely to comply with labor regulations. In addition, Bloom and Van Reenen (2010) show that labor market regulations are negatively correlated with the quality of management practices across countries. At the same time, multinational and exporting firms tend to be better managed across all countries, suggesting the better institutional environment at exporting plants offers enhanced compliance with labor regulations.

As many of the covariates in equation (4) are also dummy variables, we choose to estimate the equation using a linear probability model. Compared to a probit analysis, the linear probability model has the advantage of allowing for a straightforward interpretation of the regression coefficients. ${ }^{27}$ To take into account the occurrence of repeated observations of individuals within city-sectors, we cluster the robust standard errors at the city-sector level, though our main results are robust to clustering at the match level, as well.

\section{Main Results}

Table 5.1 reports the main results of this paper, as estimated by equation (4). As discussed, the specification controls for unobservable, time-invariant worker-plant match quality, as well as observable, time-varying worker, plant, and industry characteristics, and state-year dummies. Our main difference-in-difference equation also includes pre-determined city conditions interacted with the exogenous real exchange rate shock to control for the possibility of differential city-specific trends.

Panel A reports estimates from equation (4), where the dependent variable is a worker-plant-year

\footnotetext{
${ }^{27}$ It is well-known that in the extreme case of a fully saturated model (i.e., one where all independent variables are discrete variables for mutually-exhaustive categories), the linear probability model is completely general and the fitted probabilities lie within the interval $[0,1]$. When looking at accessions, separations, and full-time contracts, our dependent variable will be a dummy variable and applying least squares will not yield the most efficient estimator. However, as $65 \%$ of the predicted probabilities from our job creation estimation lie between 0 and 1 (60\% for job destruction, and $85 \%$ for full-time contracts), we are confident that any inconsistency is minimized.
} 
accession. Across all plants, the effect of a real exchange rate depreciation is not statistically significant, but the sign is informative. In particular, the coefficient suggests that for otherwise identical workers and plants, a depreciation of the real exchange rate decreases a worker's probability of hire. Interestingly, the point estimate on our main coefficient of interest $\left(\gamma_{1}\right)$, though insignificant, is negative, suggesting that hiring differentially increases in strictly-enforced municipalities with a shock to openness.

We argue, however, that trade shocks and regulatory enforcement have different effects depending on the plant's mode of globalization. As real exchange rate depreciations increase the competitiveness of exporting plants in foreign markets, we anticipate an expansion of employment at exporters relative to non-exporters. Therefore, we next report coefficients for the estimation of equation (4) separately for the set of exporting plants and non-exporting plants. A time-invariant export indicator is designed to minimize potential endogeneity concerns surrounding the globalization decision post-devaluation. ${ }^{28}$

As predicted by new heterogeneous firm trade models, a depreciation of the real increases hiring at exporters (insignificantly), and differentially decreases hiring at plants producing solely for the domestic market. Moreover, consistent with the literature, the way in which enforcement impacts hiring is different depending on the globalization status of the plant. Notably, enforcement has no statistical impact on exporting plants, in line with the ideas in Cardoso and Lage (2007) and the results in Harrison and Scorse (2003) for Indonesia that globalized firms are internally-enforced and more likely to comply with labor regulations. By contrast, domestic plants in strictly-enforced municipalities decrease hiring by more than otherwise identical domestic plants in weakly-enforced municipalities, as the cost of formal workers increases for these plants.

The results in Panel A suggest that the impact of trade openness differs for plants with the same mode of globalization but varying degrees of exposure to de facto labor market regulations. The magnitudes of our estimates seem to be plausible. Evaluating the effect on workers and plants located in municipalities at the mean level of inspections, a 10 percentage point depreciation of the real increases the hiring probability at exporting plants by $2.3 \%$ and decreases the hiring probability at domestic plants by $3.6 \%$, as is predicted by heterogeneous firm models of

${ }^{28}$ In unreported regressions, we test the robustness of our results to the endogeneity of the export status indicator. Specifically, we categorize plants based on the industry's import penetration. This industry-level categorization of the plant's globalization status largely confirms our main findings. 
international trade. The impact for domestic plants varies depending on the level of enforcement the plant faces-for domestic plants located in municipalities at the $10^{\text {th }}$ percentile of inspections, a 10 percentage point depreciation of the real decreases the probability of hire by only $2.5 \%$, while workers matched with domestic plants located in municipalities in the $90^{\text {th }}$ percentile of inspections experience a decrease in the accession probability of around $4.9 \%$.

Panel B of Table 5.1 reports estimates from equation (4), where the dependent variable is a workerplant-year separation, for all plants and by the plant's mode of globalization. We hypothesize that a depreciation of the real exchange rate decreases the probability of separation for the average plant, as competitiveness increases. This is confirmed in the first column of Panel B, as $\gamma_{2}$ is positive and statistically significant at the $10 \%$ level of significance. We note that, as predicted, the effect is driven by decreases in firing at expanding exporting plants.

We remind the reader that increases in inspections ambiguously relate to separations. On the one hand, more enforcement increases the cost of firing (due to the mandatory severance benefits) and thus may decrease firings. On the other hand, with increased enforcement, existing labor becomes more expensive, as there can be less evasion of labor taxes, and the plant may resort to firing workers in the short run to overcome the increased labor cost. Once again, we anticipate the impact of regulatory enforcement to be stronger for non-exporting firms where regulations are most binding. In fact, exporters in strictly-enforced municipalities respond no differently to an expansionary trade shock than do identical exporters in weakly-enforced cities. However, nonexporting plants in strictly-enforced municipalities differentially increase firing as compared to similar non-exporters facing weaker enforcement, pointing to increases in the costs of employing workers as a dominant factor. Domestic plants located in cities at the $10^{\text {th }}$ percentile of inspections contract by increasing firing by approximately $0.5 \%$ in response to a 10 percentage point devaluation, while the probability that a match is destroyed at similar domestic plants located in cities at the $90^{\text {th }}$ percentile of inspections increases by $2.3 \%$ in response to the same trade shock.

Taken together, Panels A and B of Table 5.1 suggest that stronger enforcement of labor regulations influence labor turnover along the extensive margin for non-exporting plants through increased firing and decreased hiring. That is, contracting non-exporters decrease job creation and increase job destruction even further due to increases in the cost of formal employment in strictly-regulated areas. These results offer important implications for policy. Job security in an increasingly 
globalized world receives considerable attention from academics, policymakers, and the media. Our results confirm recent trade models in which non-exporting plants contract in response to trade reform. More importantly, our data imply that labor market regulations reinforce these contractionary effects of trade reform for constrained non-exporting plants.

Expanding and contracting plants may also adjust along the intensive margin. For instance, when faced with a trade shock, employers may adjust the hours worked for existing employees or shift workers between full-time and temporary contracts. As Brazil's labor law limits a continuous work shift to 6 hours, limits the weekly working period to 44 hours, and mandates increases in overtime pay, the effects of the labor laws on plants will likely differ depending on the degree of regulatory enforcement. Similarly, the increased cost of formal labor associated with stricter enforcement of labor regulations may lead plants to shift towards the use of temporary contracts over permanent contracts. The latter could help employers overcome the long-term relationships of more restrictive employment contracts. We next consider these adjustments for all plants and by the plant's mode of globalization.

Panel C of Table 5.1 reports results from the estimation of equation (4) where the dependent variable is the logarithm of hours worked per week for all plants and by the plant's export status, while Panel D of Table 5.1 reports coefficients for the estimation of equation (4) where the dependent variable is an indicator variable equal to one if worker $i$ is employed with a full-time contract in plant $j$ in time $t$. Our data suggest little variation in the hours worked intensive margin in response to exchange rate shocks and regulatory enforcement for both exporters and nonexporters. By contrast, the data report that non-exporters facing strong increases in enforcement differentially decrease the availability of full-time contracts when compared to equivalent nonexporters in less-enforced areas, as predicted.

\subsection{Robustness of the Results}

The main results in Table 5.1 provide evidence that strong increases in labor market enforcement reinforce the contraction of non-exporting firms, by decreasing hiring, increasing firing, and decreasing the probability of full-time contracts. In this section, we test the robustness of these results. As our results indicate that most of the labor adjustment in response to trade shocks and regulatory enforcement occurs along the extensive margin, from this point forward in the paper, we 
concentrate our analysis on job creation and job destruction, but results for hours and full-time contracts are available by request.

Lagged Enforcement The endogeneity of enforcement is an important concern. As we have argued until now, we minimize this concern by focusing on within-city changes in enforcement, by focusing our interpretation on the interaction term with an exogenous trade shock, and by including statespecific year dummies and city-specific trends. In order to further allay concerns about the endogeneity of changes in enforcement, in Table 5.2 we report results from the estimation of equation (4) in which our main enforcement measure is lagged one period.

Overall, we view our results as broadly robust to the inclusion of lagged enforcement. The results in Table 5.4 are largely consistent with those presented in Table 5.1, though due to the loss of observations, we lose some statistical significance. In particular, in Panel A, though our main coefficient of interest $\left(\gamma_{1}\right)$ for non-exporters, representing the differential impact of increased exposure to enforcement, is statistically insignificant, the sign on the point estimate is consistent with Table 5.1. That is, using lagged values for enforcement, the data points to the idea that nonexporters in strictly-enforced areas differentially decrease hiring in response to an exogenous trade shock, when compared to identical non-exporting plants in weakly-enforced areas. Panel B reports results for job destruction as the dependent variable. Here, the results are entirely consistent with Table 5.1. Non-exporting plants facing strong labor market regulations differentially increase job destruction, as the cost of employing workers increases.

First-Difference Estimation Our main estimation relies on changes over time in enforcement, exchange rates, and labor market outcomes. Econometrically, we rely on fixed effects to consider these changes over time for workers and firms producing in different cities and industries. It is well known that the fixed effects estimator is efficient when the errors are serially uncorrelated. However, Bertrand, Duflo, and Mullainathan (2004) remark that errors may be serially correlated in difference-in-difference estimations like ours. Our results until now have adjusted for this by clustering the standard errors at the city-industry level. In unreported results, we also show that our findings are robust to clustering the standard errors at the match level.

In Table 5.3, we test the importance of our choice of the fixed effects estimator. We instead estimate equation (4) in first-differences and show that the main results are robust. Heavily-inspected non- 
exporters differentially contract by increasing firing and decreasing hiring in response to a trade shock relative to identical non-exporters in less-inspected cities.

\subsection{Heterogeneity of the Results}

Our main results provide suggestive evidence that non-exporters facing strict labor market regulations differentially decrease job creation and differentially increase job destruction in response to trade openness, as compared to similar plants located in areas with weak labor market regulatory enforcement. In this section, we consider the heterogeneity of these results based on industry-level differences such as the sector's technological intensity, based on plant-level differences such as total employment, and based on worker-level differences such as the worker's age group. Again, given the lack of statistical evidence in support of strong adjustments along the intensive margin, we restrict the analysis to the impact on job creation and job destruction. The results for hours and contract type are available upon request.

Technological Intensity $\quad$ Our main argument rests on the fact that a trade shock will reallocate factors of production towards more efficient use. We consider labor as the relevant factor of production in this paper. However, the same shock may also influence adjustments in the short-run in terms of capital or other physical materials factors of production. To ensure that the effects of labor market regulatory enforcement we find in Table 5.1 reflects plants' constraints in adjusting labor in the short-run, we split our main sample into sectors depending on technological intensity. Our assumption here, consistent with much of the literature, is that sectors relying on technology are relatively capital-intensive. Therefore, low technology sectors are assumed to be more laborintensive. For this reason, we anticipate that our main findings are driven by plants in low-tech (labor-intensive) industries. We rely on data from the World Bank's Investment Climate Assessment Reports to define sectors' technological intensity. ${ }^{29}$ Examples of high-tech industries are: petroleum refining, chemical manufacturing, and automobile manufacturing. Examples of low-tech industries are: food and beverage, textile, and wood manufacturing.

We report coefficients from the estimation of equation (4) by the sector's technological intensity in Table 5.4. In the top panel, the dependent variable represents an indicator for job creation, while in

${ }^{29}$ CNAE 2-digit codes 23-24 and 26-35 are defined as high-tech sectors, while CNAE 2-digit codes 15-22, 25, 36-37 are defined as low-tech sectors. 
the bottom panel, we use a job destruction indicator as the dependent variable. The results are mostly in line with our hypotheses. The differential decrease in hiring at strictly-enforced nonexporters appears to hold across low-tech and high-tech industries, although the point estimate on our main coefficient of interest is marginally larger in magnitude for labor-intensive non-exporters. In addition, the finding that domestic plants located in strictly-enforced areas increase job destruction by more is largely driven by domestic plants in low-tech industries. The main interaction parameter of interest is negative and statistically significant at the $10 \%$ level of significance.

Plant Size As is emphasized in Cardoso and Lage (2007), there is a strong correlation between the size of the firm, as a proxy for the visibility of the firm, and the number of inspections. The results in Kugler (2004) reinforce this finding. The author reports Colombian labor market reforms had a greater impact on workers in larger firms. Moreover, it is now well-established in the international economics literature that exporters and non-exporters differ substantially in terms of productivity and size, among other attributes (Bernard and Jensen 1995). For these reasons, we next explore the heterogeneity of our main findings by the size of the plant. We define a time-invariant large plant indicator equal to one for those plants with average employment between 1996 and 2001 greater than the median value. We argue that comparing similarly-sized plants helps to minimize any possible selection bias associated with the plant's globalization status.

Table 5.5 displays results from the estimation of equation (4), by the size of the plant, for all plants and by the plant's mode of globalization, where the dependent variable in the top panel is a workerplant job creation and the dependent variable in the bottom panel is a worker-plant job destruction. We note that the positive interaction coefficient for the set of non-exporters in Panel A of Table 5.1 and the negative interaction coefficient for the set of non-exporters in Panel B of Table 5.1 are wholly driven by the impact on below-median sized plants. Small, non-exporters are those plants for which labor market regulations are most likely to be binding and restrictive. Due to their visibility, as is suggested by Cardoso and Lage (2007), large plants are already likely to comply with existing regulations, such that increases in inspections have no statistical impact. As such, small non-exporters who experienced an increase in enforcement over our sample period demonstrate significant differences in job creation and job destruction in response to trade reform as compared to similar plants facing less labor market regulatory enforcement. 
In addition, we note that when comparing large exporters to large non-exporters, the main coefficients on the trade-weighted real exchange rate remain statistically significant and of the same sign in comparison to Table 5.1. Considering similarly-sized plants helps to minimize potential bias associated with selection into exporting post-trade reform. In this respect, our results are further robust to the potential for the endogeneity of export status.

Worker Age Our main findings show that, following a trade shock, labor adjustment (particularly at non-exporting plants) varies depending on the degree of enforcement of labor market regulations. However, in addition to this main effect, the composition of employment is also likely to be affected by the stringency of enforcement of labor regulations. We hypothesize that in environments facing strict enforcement, those already employed are more likely to remain employed, while new entrants or re-entrants into the labor force-as is likely the case with younger workers-are less likely to be hired. Table 5.6 reports estimates for equation (4), dividing the sample by the age of the worker and the plant's globalization status. We define workers as "older" when they are 31 and older (the median worker age in the sample) and "younger" when they are 30 or less.

As predicted, we see that increases in de facto labor regulations decrease the hiring of young workers at non-exporting plants. The sign on the main interaction term therefore shows that, in response to a real exchange rate depreciation, non-exporting plants in strictly-enforced municipalities differentially decrease hiring of youth workers in particular. Similarly, the result that non-exporters in strictly-enforced municipalities differentially increase job destruction relative to non-exporters in weakly-enforced areas is driven by the impact on young workers, as well.

\subsection{Aggregate Implications}

A key argument in favor of trade liberalizing reforms is that factors can reallocate to more efficient uses, allowing for enhanced productivity and growth. However, in this paper we demonstrate that the efficient reallocation of labor in response to trade shocks is inhibited by strict de facto labor market regulations. In this section, we investigate the extent to which dampened labor reallocation also restricts the within plant productivity gains associated with trade openness.

There are a few potential channels linking increased enforcement to lower plant-level productivity. 
For instance, the inability of plants to adjust to changing conditions and to reallocate from declining to dynamic sectors may reduce plant-level productivity. In addition, more regulations may prevent plants from introducing new goods or investing in more complex production technologies which may have higher value-added, but also face more volatile demand and thus require greater adjustments. Finally, given the high costs of dismissals in areas with strict employment protection, employers may now be forced to retain unproductive workers they would have otherwise fired. Also, given the expectation of a job-for-life, employees may now have less incentive to exert effort, thus lowering their plant and worker productivity.

On the other hand, we can also imagine effects in the other direction; that is, stricter regulations increasing plant-level productivity. As labor market regulations increase the costs associated with formal employment, plants may also raise the bar for the quality of workers they are willing to hire, given the increased costs, and consequently increase plant-level productivity. Moreover, the expectation of a long-term relationship may increase investments in plant-specific training, which neither the employer nor the worker would be willing to incur if the relationship was short-term. Finally, businesses may switch away from hiring workers and use mechanized technologies to replace workers, which may raise productivity for the remaining workers.

In the absence of direct data on plant-level productivity and profitability, we rely on information on plant-level average wages under the assumption that increases in productivity and profitability will be positively associated with increases in plant-average wages when plants share rents with workers. $^{30}$ In Table 5.7, we present coefficients from the estimation of equation (2), where the dependent variable is the plant-level average wage as a proxy for plant-level productivity. Across all plants, a depreciation significantly increases within-plant productivity (consistent with studies like Pavcnik (2002)). We also find a negative impact of increased enforcement on plant-level productivity, as proxied by plant-average wages, suggesting that the first effect pertaining to restricted labor reallocation dominates any potential positive impact of enforcement on firm productivity via increases in investments in training or physical capital.

Our focus, however, is on the interaction term, where our predictions are confirmed. Across all plants, strict enforcement of labor regulations limits potential within-plant productivity gains (due

\footnotetext{
${ }^{30}$ For instance, in a model like the one in Amiti and Davis (2012), where workers' wages are directly linked to firm profits through a "fair wage" mechanism.
} 
to the efficient reallocation of workers) associated with trade openness. As before, these effects are wholly concentrated among constrained non-exporting plants, as strong regulatory enforcement inhibits the potential for productivity gains.

\section{Conclusions and Policy Implications}

Economists have long debated the effects of trade liberalization on labor market outcomes in developing countries. Early studies found little impact on plant-level employment changes. We argue a potential explanation relates to how restrictive labor market regulations are in inhibiting the reallocation of workers. In this paper, we revisit the question of the impact of trade liberalization on labor reallocation using data for Brazil. Brazil is an especially interesting case study given the stringency of the de jure labor market regulations in the country (see Botero, et al (2004)). Furthermore, the topic is also at the forefront of economic policy discussions as the country considers new ways of fostering industrial productivity and of creating a more competitive workforce. ${ }^{31}$ Finally, the size and geographic heterogeneity of the country also creates significant variation within the country on the enforcement of the labor law.

We explore the fact that within countries, plants vary in the degree of exposure to global markets and in the incidence of de facto labor regulations they face. We use a difference-in-difference methodology to identify the effects of openness on labor turnover, for firms with different degrees of exposure to trade and de facto labor regulations. In particular, we analyze the impact of increased exposure to trade, following Brazil's currency crisis in 1999, and discern the impact depending on the plant's exposure to global markets and to the enforcement of labor market regulations based on the plant's municipal location.

We show that, in Brazil, the extent to which trade affects labor market outcomes depends on the de facto degree of stringency of the labor regulations faced by plants. Conditional on several timevarying worker, plant, city, and sector characteristics, we note that, as is predicted by new heterogeneous firm trade models, trade openness is associated with an expansion at exporting

\footnotetext{
${ }^{31}$ For example, the Brazilian government has recently launched a program of incentives to promote industrial growth and competitiveness. The program proposes an exemption from a $20 \%$ social security levy on worker payrolls for certain sectors. Eligible sectors include automotives, textiles, footwear, and plastics (see Financial Times 2012).
} 
plants and a relative contraction at domestically-oriented plants. Furthermore, we find that labor inspections largely influence labor adjustment along the extensive margin at small, labor-intensive, non-exporting firms for which labor regulations are most binding. This is an especially interesting finding for policymakers, given the current challenge of revamping industrial growth, through a more competitive labor force, in the face of a globalizing world.

Our results strongly suggest that in a setting of stringent de jure regulations, with enhanced trade openness increasing enforcement limits job creation. Overall, stricter labor enforcement increases job destruction and decreases job creation at plants most restricted by labor regulations. We also show this increased enforcement is associated with lower productivity gains post-trade reform. From a policy standpoint, our work also suggests that in Brazil increasing the flexibility of de jure labor regulations will allow for increased job creation and thus offer broader access to the gains from trade. 


\section{References}

Aghion, Philippe, Robin Burgess, Stephen J. Redding, and Fabrizio Zilibotti. 2008. "The Unequal Effects of Liberalization: Evidence from Dismantling the License Raj in India," American Economic Review, 98 (4), pp. 1397-1412.

Aguayo-Tellez, Ernesto, Marc-Andreas Muendler, and Jennifer P. Poole, 2010. "Globalization and Formal-Sector Migration in Brazil,” World Development, 38 (6), pp. 840-856.

Ahsan, Ahmad and Carmen Pages, 2009. "Are All Labor Regulations Equal? Evidence from Indian Manufacturing," Journal of Comparative Economics, 37 (1), pp. 62-75.

Almeida, Rita and Pedro Carneiro, 2012. "Enforcement of Labor Regulation and Informality" American Economic Journal: Applied Economics, 4 (3), pp. 64-89.

Amiti, Mary and Donald R. Davis, 2012. “Trade, Firms, and Wages: Theory and Evidence," Review of Economic Studies, 79, pp. 1-36.

Autor, David, William R. Kerr, and Adriana Kugler, 2007. "Does Employment Protection Reduce Productivity? Evidence from US States,” The Economic Journal, 117, pp. 189-217.

Barros, Ricardo P. and Carlos H. Corseuil, 2004. "The Impact of Regulations on Brazilian Labor Market Performance," in James J. Heckman and Carmen Pages, Eds., Law and Employment: Lessons from Latin America and the Caribbean, Chicago: The University of Chicago Press.

Bernard, Andrew B. and J. Bradford Jensen, 1995. "Exporters, Jobs and Wages in U.S. Manufacturing, 1976-87," Brookings Papers on Economic Activity: Microeconomics, pp. 67-112.

Bertola, Giuseppe, Tito Boeri, and Sandrine Cazes, 2000. "Employment Protection in Industrialized Countries: The Case for New Indicators," International Labour Review, 139 (1), pp. 57-72.

Bertrand, Marianne, Esther Duflo, and Sendhil Mullainathan, 2004. "How Much Should We Trust Difference-in-Differences Estimates?,” Quarterly Journal of Economics, 119 (1), pp. 249-275.

Besley, Timothy and Robin Burgess, 2004. "Can Labor Regulation Hinder Economic Performance? Evidence from India," The Quarterly Journal of Economics, CXIX, pp. 91-134.

Bloom, Nicholas and John Van Reenen, 2010. "Why Do Management Practices Differ across Firms and Countries?" Journal of Economic Perspectives, 24 (1), pp. 203-224.

Botero, Juan C., Simeon Djankov, Rafael La Porta, and Florencio López de Silanes, 2004. "The Regulation of Labor," The Quarterly Journal of Economics, 119 (4), pp. 1339-1382.

Brambilla, Irene, Daniel Lederman, and Guido Porto, 2012. "Exports, Export Destinations, and Skills," American Economic Review, 102 (7), pp. 3406-3438.

Broda, Christian and David E. Weinstein, 2006. "Globalization and the Gains from Variety," The Quarterly Journal of Economics, 121 (2), pp. 541-585. 
Burgess, Simon M. and Michael M. Knetter, 1998. "An International Comparison of Employment Adjustment to Exchange Rate Fluctuations," Review of International Economics, 6 (1), pp. 151163.

Bustos, Paula, 2011. "The Impact of Trade Liberalization on Skill Upgrading: Evidence from Argentina," unpublished manuscript.

Caballero, Ricardo J., Kevin N. Cowan, Eduardo M.R.A. Engel, and Alejandro Micco, 2013. "Effective Labor Regulation and Microeconomic Flexibility," Journal of Development Economics, 101, pp. 92-104.

Campa, Jose Manuel and Linda S. Goldberg, 2001. "Employment versus Wage Adjustment and the U.S. Dollar," The Review of Economics and Statistics, 83 (3), pp. 477-489.

Cardoso, Adalberto and Telma Lage, 2007. As Normas e os Fatos, Editora FGV, Rio de Janeiro, Brasil.

Coşar, A. Kerem, Nezih Guner, and James R. Tybout, 2011. "Firm Dynamics, Job Turnover, and Wage Distributions in an Open Economy," unpublished manuscript.

Currie, Janet and Ann E. Harrison, 1997. "Sharing the Costs: The Impact of Trade Reform on Capital and Labor in Morocco," Journal of Labor Economics, 15(3), pp. 44-71.

Eslava, Marcela, John Haltiwanger, Adriana Kugler, and Maurice Kugler, 2010. "Factor Adjustments after Deregulation: Panel Evidence from Colombian Plants," The Review of Economics and Statistics, 92 (2), pp. 378-391.

Fajgelbaum, Pablo D., 2012. "Labor Market Frictions, Firm Growth, and International Trade," unpublished manuscript.

Feenstra, Robert C., Robert E. Lipsey, Haiyan Deng, Alyson C. Ma, and Hengyong Mo, 2004. "World Trade Flows: 1962-2000," NBER Working Paper No. 11040.

Feliciano, Zadia M., 2001. "Workers and Trade Liberalization: The Impact of Trade Reforms in Mexico on Wages and Employment," Industrial and Labor Relations Review, 55 (1), pp. 95-115.

Feyrer, James, 2009. "Trade and Income-Exploiting Time Series in Geography," unpublished manuscript.

The Financial Times, 2012. “Brazil Unveils Measures to Boost Industry,” April 3, 2012.

Freund, Caroline and Bineswaree Bolaky, 2008. "Trade, regulations, and income," Journal of Development Economics, 87 (2), pp. 309-321.

Goldberg, Linda S., 2004. "Industry-specific exchange rates for the United States," Economic Policy Review, Federal Reserve Bank of New York, May, pp. 1-16.

Goldberg, Linda S. and Joseph Tracy, 2003. "Exchange Rates and Local Labor Markets," in Robert C. Feenstra, Ed., The Impact of International Trade on Wages, Chicago: The University of Chicago Press. 
Goldberg, Pinelopi and Nina Pavcnik, 2003. "The Response of the Informal Sector to Trade Liberalization," Journal of Development Economics, 72, pp. 463-496.

Gonzaga, Gustavo, Naercio Aquino Menezes-Filho, and Cristina Terra, 2006. "Trade Liberalization and the Evolution of Skill Earnings in Brazil," Journal of International Economics, 68 (2), pp. 345367.

Gruben, William C. and Sherry Kiser, 1999. "Brazil: The First Financial Crisis of 1999," Southwest Economy, pp. 13-14.

Harrison, Ann and Jason Scorse, 2003. “Globalization's Impact on Compliance with Labor Standards," Brookings Trade Forum, pp. 45-96.

Hasan, Rana, Devashish Mitra, and K.V Ramaswamy, 2007. "Trade Reforms, Labor Regulations, and Labor-Demand Elasticities: Empirical Evidence from India," The Review of Economics and Statistics, 89 (3), pp. 466-481.

Heckman, James J. and Carmen Pages, 2004. Law and Employment: Lessons from Latin America and the Caribbean, Chicago: The University of Chicago Press.

Helpman, Elhanan, Oleg Itskhoki, and Stephen Redding, 2010. "Inequality and Unemployment in a Global Economy," Econometrica, 78 (4), pp. 1239-1283.

Hsieh, Chang-Tai and Peter J. Klenow, 2009. "Misallocation and Manufacturing TFP in China and India," The Quarterly Journal of Economics, 124, pp. 1403-1448.

Kambourov, Gueorgui, 2009. "Labor Market Regulations and the Sectoral Reallocation of Workers: The Case of Trade Reforms," The Review of Economic Studies, 76 (4), pp. 1321-1358.

Kaplan, David S., 2009. "Job Creation and Labor Reform in Latin America," Journal of Comparative Economics, 37, pp. 91-105.

Krishna, Pravin, Jennifer P. Poole, and Mine Zeynep Senses, 2011. "Wage Effects of Trade Reform with Endogenous Worker Mobility," NBER Working Paper No. 17256.

Kugler, Adriana, 1999. "The Impact of Firing Costs on Turnover and Unemployment: Evidence from the Colombian Labor Market Reform," International Tax and Public Finance Journal, 6(3).

Kugler, Adriana, 2004. "The Effect of Job Security Regulations on Labor Market Flexibility: Evidence from the Colombian Labor Market Reform," in James J. Heckman and Carmen Pages, Eds., Law and Employment: Lessons from Latin America and the Caribbean, Chicago: The University of Chicago Press.

Kugler, Adriana and Maurice Kugler, 2009. "Labor Market Effects of Payroll Taxes in Developing Countries: Evidence from Colombia," Economic Development and Cultural Change, 57 (2), pp. 335-358.

Kume, Honório, Guida Piani, and Carlos Frederico Bráz de Souza, 2003. "A Política Brasileira de Importacão no Período 1987-98: Descricão e Avaliacão," in Carlos Henrique Corseuil and 
Honório Kume, eds., A abertura comercial brasileira nos anos 1990: Impactos sobre emprego e salários, Rio de Janeiro: MTE and IPEA, chapter 1, 9-37.

Melitz, Marc J., 2003. "The Impact of Trade on Intra-Industry Reallocations and Aggregate Industry Productivity," Econometrica, 71 (6), pp. 1695-1725.

Menezes-Filho, Naercio Aquino and Marc-Andreas Muendler, 2011. "Labor Allocation in Response to Trade Reform," unpublished manuscript.

Moreira, Mauricio Mesquita and Correa, Paulo Guilherme, 1998. "A first look at the impacts of trade liberalization on Brazilian manufacturing industry," World Development, 26 (10), pp. 18591874.

Muendler, Marc-Andreas, 2003. "Nominal and Real Exchange Rate Series for Brazil, 1986-2001," unpublished manuscript.

Olarreaga, Marcelo and Isidro Soloaga, 1998. "Endogenous Tariff Formation: The Case of Mercosur," World Bank Economic Review, 12 (2), pp. 297-320.

Pavcnik, Nina, 2002. "Trade Liberalization, Exit, and Productivity Improvements: Evidence from Chilean Plants," The Review of Economic Studies, 69, pp. 245-276.

Paz, Lourenço, 2012. "The Impacts of Trade Liberalization on Informal Labor Markets: A Theoretical and Empirical Evaluation of the Brazilian Case," unpublished manuscript.

Petrin, Amil and Jagadeesh Sivadasan, forthcoming. "Estimating Lost Output from Allocative Inefficiency, with an Application to Chile and Firing Costs", The Review of Economics and Statistics.

Revenga, Ana L., 1992. "Exporting Jobs?: The Impact of Import Competition on Employment and Wages in U.S. Manufacturing," The Quarterly Journal of Economics, 107 (1), pp. 255-284.

Ribeiro, Eduardo Pontual, Carlos H. Conseuil, Daniel Santos, Paulo Furtado, Brunu Amorim, Luciana Servo, and Andree Souza, 2004. "Trade Liberalization, the Exchange Rate, and Job Flows in Brazil," The Journal of Policy Reform, 74 (4), pp. 209-223.

Topalova, Petia, 2010. "Factor Immobility and Regional Impacts of Trade Liberalization: Evidence on Poverty from India," American Economic Journal: Applied Economics, 2, pp. 1-41.

Verhoogen, Eric, 2008. "Trade, Quality Upgrading and Wage Inequality in the Mexican Manufacturing Sector," The Quarterly Journal of Economics, 123 (2), pp. 489-530.

Yeaple, Stephen Ross, 2005. "A Simple Model of Firm Heterogeneity, International Trade and Wages," Journal of International Economics, 65, pp. 1-20.

Woodcock, Simon D., 2011. “Match Effects,” unpublished manuscript. 
Figure 3.1: Nominal and Real Exchange Rate Series for Brazil, 1994 - 2001

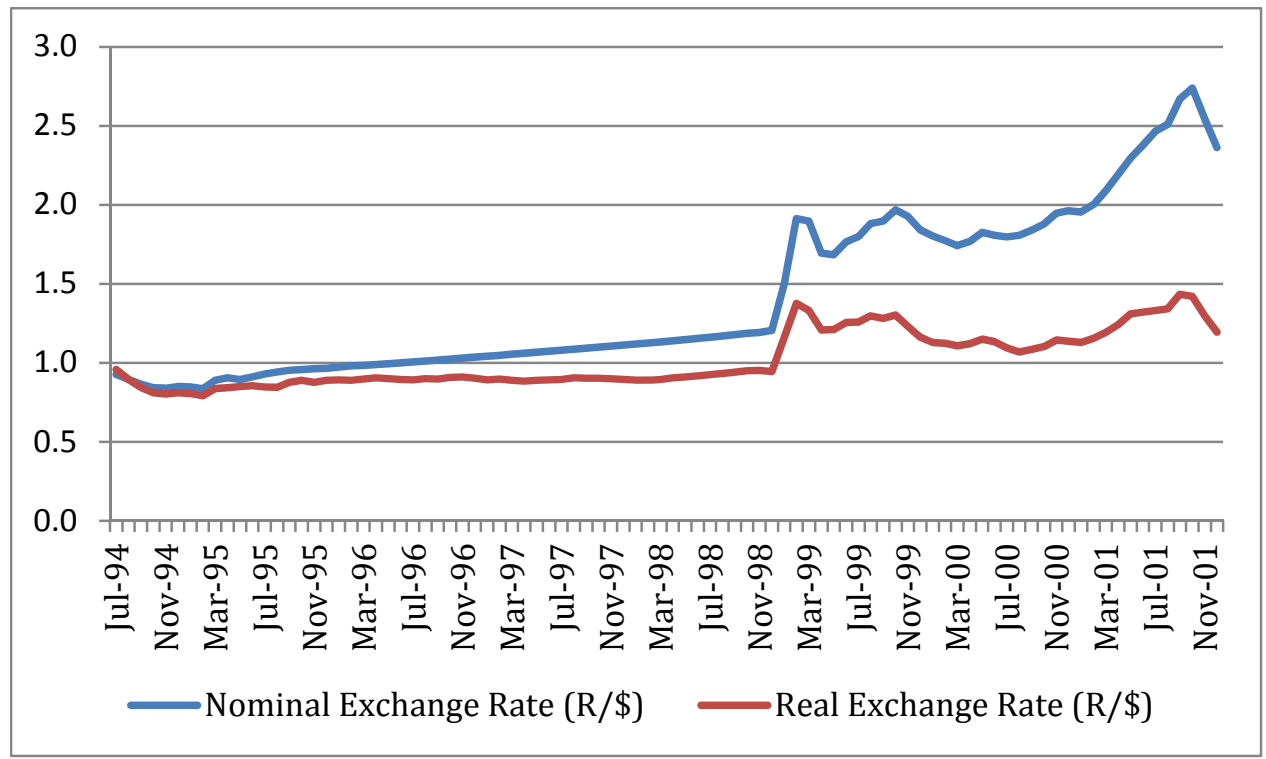

Source: Muendler (2003). 
Figure 3.2: Enforcement Intensity by Municipality, 1998 and 2000

1998

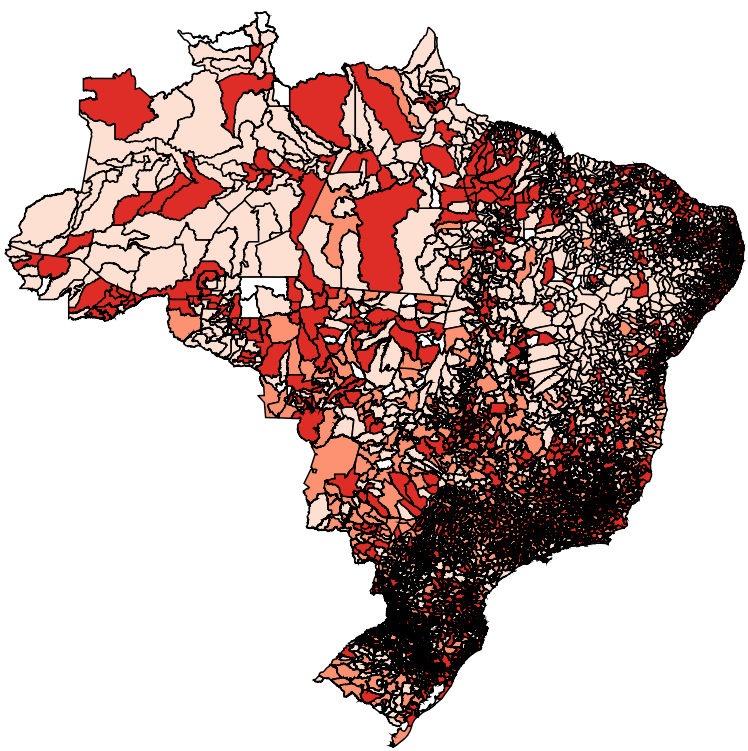

2000

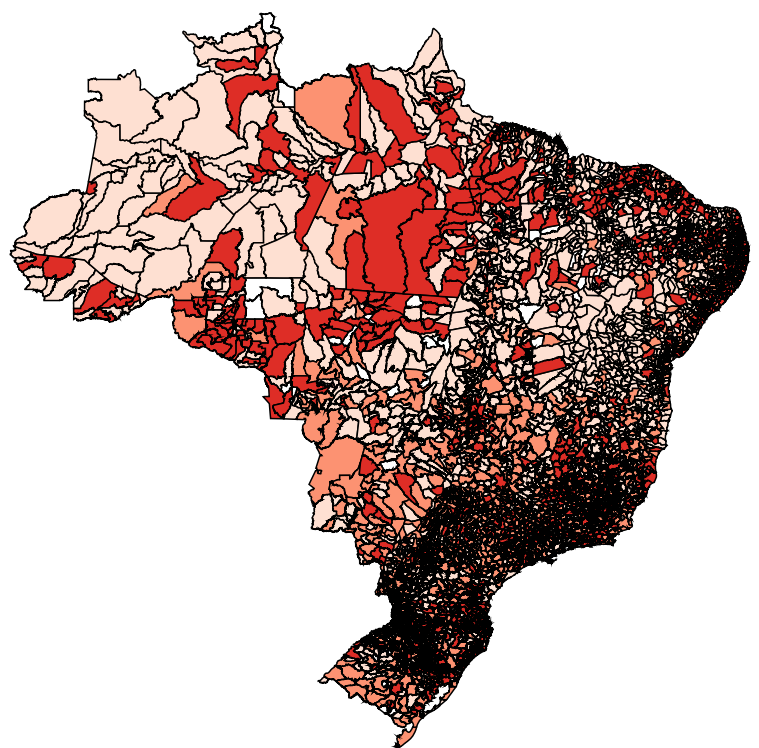

Source: Authors' calculations based on administrative data from the Brazilian Ministry of Labor (1996-2001).

Note: This figure reports the average number of inspections per 100 plants by Brazilian municipality, with darker shades representing higher numbers of inspections. The map on the left is for the year 1998, while the map on the right is for the year 2000 .

Figure 3.3: Enforcement Intensity by Municipality, Mato Grosso, 1998 and 2000

1998

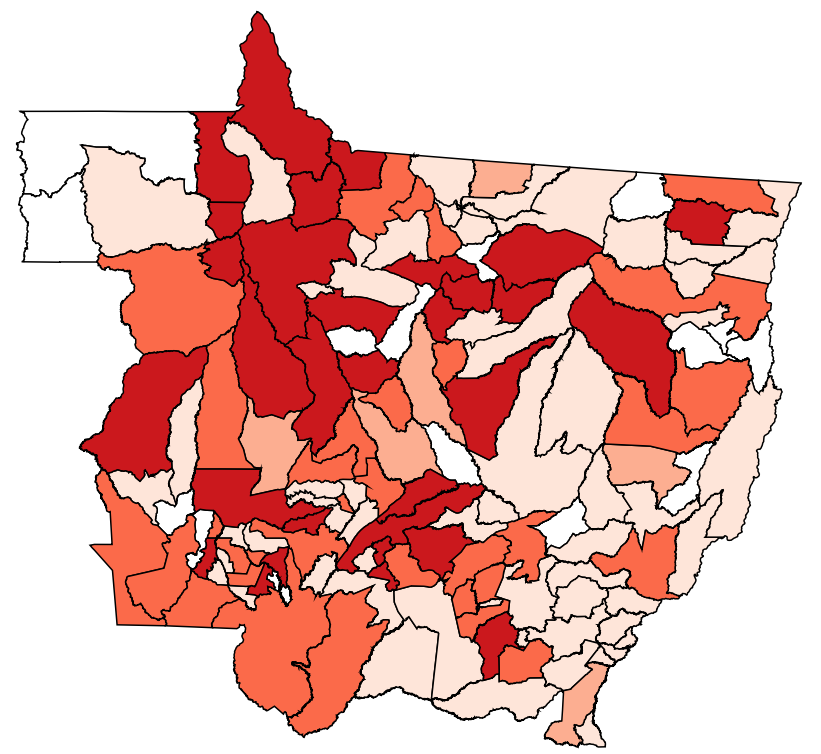

2000

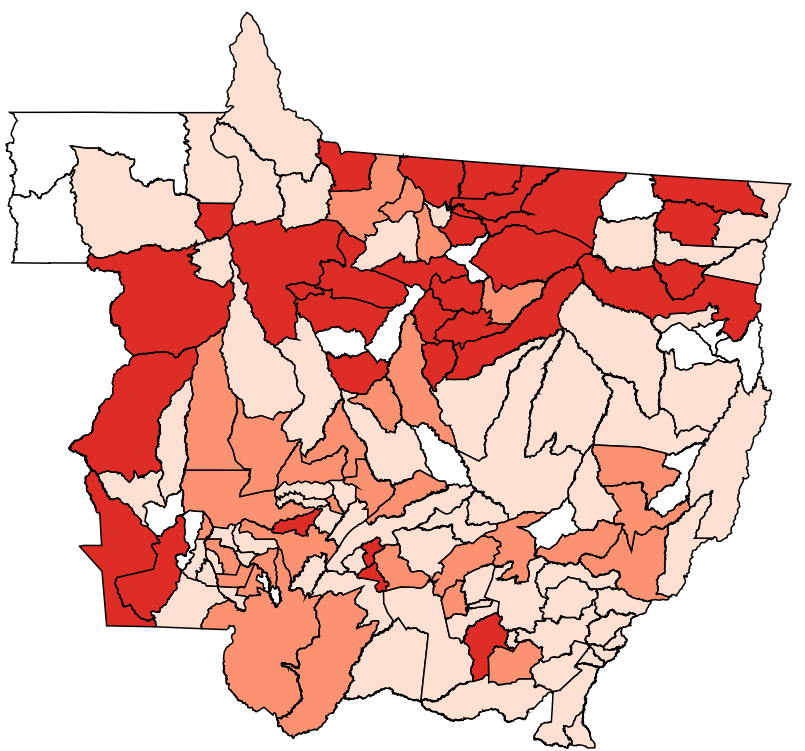

Source: Authors' calculations based on administrative data from the Brazilian Ministry of Labor (1996-2001).

Note: This figure reports the average number of inspections per 100 plants by Brazilian municipality for the state of Mato Grosso, with darker shades representing higher numbers of inspections. The map on the left is for the year 1998, while the map on the right is for the year 2000 . 
Figure 3.4: Industry Variation in Trade-Weighted RER (Levels and Changes), 1999

Trade-Weighted RER

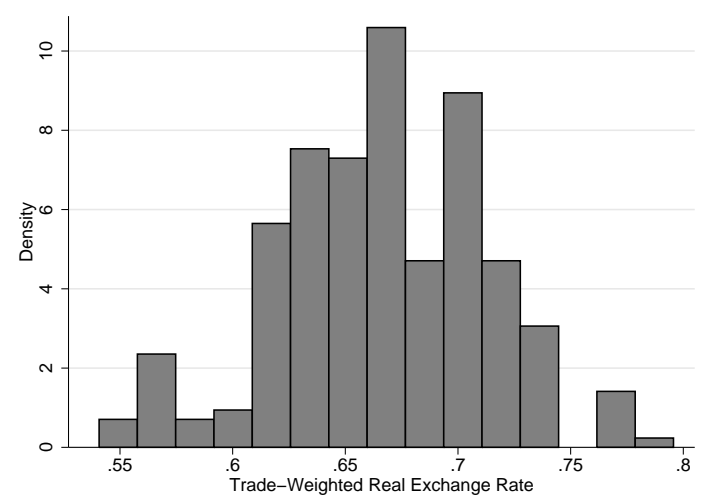

Changes in Trade-Weighted RER

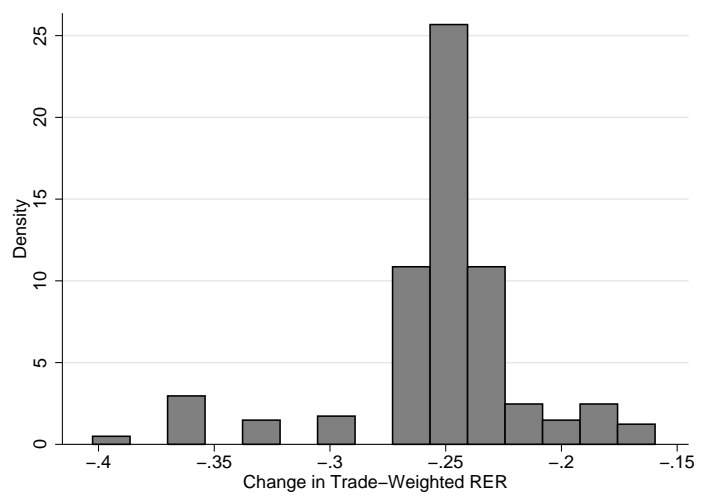

Source: Authors' calculations based on bilateral real exchange rate data from the IMF and trade flows data from the NBER (1998-1999).

Note: This figure illustrates industry-level heterogeneity in the level of the trade-weighted real exchange rate (left panel) and in the annual change of the trade-weighted real exchange rate (right panel). 
Table 3.1: Enforcement Data, 1996-2001

\begin{tabular}{|c|c|c|c|c|}
\hline & $\begin{array}{l}\text { Share of Cities } \\
\text { Inspected }\end{array}$ & $\begin{array}{c}\text { Average } \\
\text { Number of } \\
\text { Inspections in } \\
\text { each City }\end{array}$ & $\begin{array}{l}\text { Average } \\
\text { Number of } \\
\text { Inspections } \\
\text { Per } 100 \\
\text { Registered } \\
\text { Plants }\end{array}$ & $\begin{array}{l}\text { Average } \\
\text { Number of } \\
\text { Inspections } \\
\text { Per } 10,000 \\
\text { Registered } \\
\text { Workers }\end{array}$ \\
\hline 1996 & 0.33 & 13.2 & 1.92 & 13.17 \\
\hline 1997 & 0.44 & 13.0 & 2.01 & 16.04 \\
\hline 1998 & 0.38 & 12.8 & 2.33 & 20.35 \\
\hline 1999 & 0.50 & 13.8 & 2.56 & 21.06 \\
\hline 2000 & 0.43 & 14.8 & 2.62 & 22.38 \\
\hline 2001 & 0.52 & 14.3 & 2.26 & 16.23 \\
\hline \multicolumn{5}{|c|}{$\begin{array}{l}\text { Source: Authors' calculations based on administrative data from the Brazilian Ministry of Labor (1996- } \\
\text { 2001). } \\
\text { Note: This table reports different statistics at the city level between } 1996 \text { and 2001. Column (1) reports } \\
\text { the share of cities that have at least one manufacturing labor inspection. Column (2) reports the average } \\
\text { number of labor inspections in each city. Column (3) reports the average number of inspections per } 100 \\
\text { registered plants in the city and column (4) reports the average number of labor inspections per 10,000 } \\
\text { registered workers ("com carteira "). }\end{array}$} \\
\hline
\end{tabular}


Table 3.2: Changes in Enforcement, 1996-2001

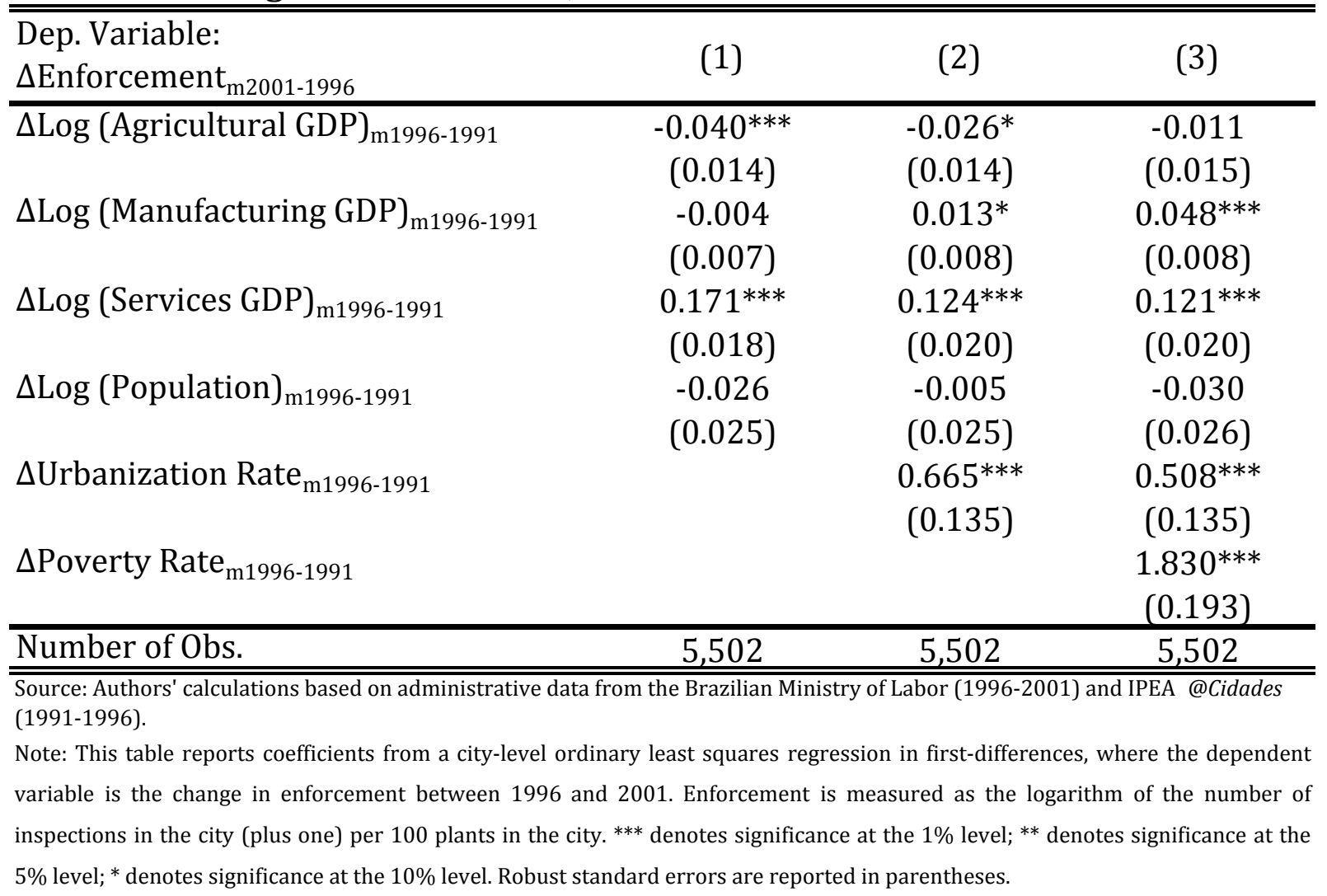




\begin{tabular}{|c|c|c|c|}
\hline & All Plants & Exporters & Non-Exporters \\
\hline \multicolumn{4}{|l|}{ Share of workers: } \\
\hline Hired & 0.33 & 0.27 & 0.39 \\
\hline Fired & 0.29 & 0.26 & 0.33 \\
\hline Temporary Contract & 0.02 & 0.02 & 0.02 \\
\hline \multicolumn{4}{|l|}{ Average: } \\
\hline Hours Per Week & 43.5 & 43.4 & 43.6 \\
\hline \multicolumn{4}{|l|}{ Worker-level Covariates } \\
\hline Age & 32 & 32 & 31 \\
\hline \multicolumn{4}{|l|}{ Share of workers: } \\
\hline Less than High School & 0.68 & 0.62 & 0.74 \\
\hline High School & 0.26 & 0.28 & 0.23 \\
\hline More than High School & 0.07 & 0.10 & 0.03 \\
\hline Unskilled Blue Collar & 0.11 & 0.10 & 0.11 \\
\hline Skilled Blue Collar & 0.65 & 0.64 & 0.67 \\
\hline Other White Collar & 0.07 & 0.07 & 0.07 \\
\hline Professional or Technical & 0.17 & 0.19 & 0.15 \\
\hline \multicolumn{4}{|l|}{ Plant-level Covariates } \\
\hline Employment & 99 & 233 & 40 \\
\hline Average Wage (in logs) & 7.98 & 8.47 & 7.76 \\
\hline \multicolumn{4}{|l|}{ Municipality-level Covariates } \\
\hline Inspections & 41.6 & 68.3 & 44.7 \\
\hline \multicolumn{4}{|l|}{ Industry-level Covariates } \\
\hline Trade-weighted RER & 0.81 & 0.81 & 0.81 \\
\hline Employment & 17,390 & 17,717 & 17,983 \\
\hline Unionization Rate & 0.22 & 0.22 & 0.22 \\
\hline Number of Observations & 322,614 & 169,890 & 152,724 \\
\hline Number of Workers & 109,086 & 55,207 & 63,060 \\
\hline Number of Plants & 61,462 & 13,921 & 47,541 \\
\hline Number of Municipalities & 2,829 & 1,407 & 2,698 \\
\hline Number of Industries & 240 & 237 & 239 \\
\hline \multicolumn{4}{|c|}{$\begin{array}{l}\text { Source: Authors' calculations based on RAIS, administrative data from the Brazilian Ministry of Labor, IMF bilateral real } \\
\text { exchange rates, NBER trade flows, and SECEX (1996-2001). }\end{array}$} \\
\hline \multicolumn{4}{|c|}{$\begin{array}{l}\text { Note: This table reports descriptive statistics for the main variables used in our empirical work, across all plants and by } \\
\text { the plant's mode of globalization. We report on worker-level variables (averages across workers), plant-level variables } \\
\text { (averages across plants), municipality-level variables (averages across municipalities), and industry-level variables } \\
\text { (averages across industries). }\end{array}$} \\
\hline
\end{tabular}


Table 4.1: Trade, Enforcement, and Plant-Level Employment

\begin{tabular}{|c|c|c|c|}
\hline $\begin{array}{l}\text { Dep. Variable: } \\
\text { Log }(\text { Employment })_{j \mathrm{jkt}}\end{array}$ & (1) & (2) & (3) \\
\hline TRER $_{\mathrm{kt}}{ }^{*}$ Enforcement ${ }_{\mathrm{mt}}$ & & $\begin{array}{l}0.047^{* * *} \\
(0.006)\end{array}$ & $\begin{array}{l}0.034^{* *} \\
(0.015)\end{array}$ \\
\hline Trade-weighted $\mathrm{RER}_{\mathrm{kt}}$ & $\begin{array}{c}-0.137^{* * *} \\
(0.046) \\
\end{array}$ & $\begin{array}{c}-0.394^{* * *} \\
(0.052) \\
\end{array}$ & $\begin{array}{c}-0.192^{* * *} \\
(0.051) \\
\end{array}$ \\
\hline Number of Obs. & 269,422 & 269,422 & 269,422 \\
\hline Plant-Year Controls & YES & YES & YES \\
\hline Sector-Year Controls & YES & YES & YES \\
\hline State-Year Dummies & YES & YES & YES \\
\hline Plant Fixed Effects & YES & YES & YES \\
\hline \multicolumn{4}{|c|}{$\begin{array}{l}\text { Source: Authors' calculations based on RAIS, administrative data from the Brazilian Ministry of Labor, IMF bilateral real } \\
\text { exchange rates, and NBER trade flows (1996-2001). } \\
\text { Note: This table reports coefficients from the ordinary least squares estimation of equations (1) and (2) in the paper, } \\
\text { where the dependent variable is the logarithm of plant-level employment. In columns (1) and (2), enforcement is } \\
\text { measured as the logarithm of the number of inspections in the city (plus one). In column (3), enforcement is measured as } \\
\text { the logarithm of the number of inspections in the city (plus one) per } 100 \text { plants in the city. }{ }^{* *} \text { denotes significance at the } \\
1 \% \text { level; }{ }^{* *} \text { denotes significance at the } 5 \% \text { level; }{ }^{*} \text { denotes significance at the } 10 \% \text { level. Robust standard errors, } \\
\text { clustered at the city-industry level, are reported in parentheses. All regressions also include city-level enforcement. } \\
\text { Unreported covariates at the plant-level include average worker tenure at the plant, the age, gender, educational, and } \\
\text { occupational composition of the plant. Unreported industry-level covariates include the unionization rate, industry } \\
\text { employment, average worker tenure in the industry, and the age, gender, educational, and occupational composition of } \\
\text { the industry. }\end{array}$} \\
\hline
\end{tabular}




\begin{tabular}{|c|c|c|c|}
\hline & All & Exporters & Non-Exporters \\
\hline & \multicolumn{3}{|c|}{ PANEL A: Job Creation } \\
\hline \multirow[t]{2}{*}{ 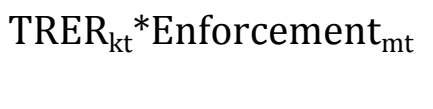 } & -0.024 & -0.017 & $0.034^{*}$ \\
\hline & $(0.015)$ & $(0.020)$ & $(0.019)$ \\
\hline \multirow{3}{*}{ Trade-weighted $\mathrm{RER}_{\mathrm{kt}}$} & 0.051 & -0.143 & $0.185^{* *}$ \\
\hline & $(0.069)$ & $(0.089)$ & $(0.093)$ \\
\hline & \multicolumn{3}{|c|}{ PANEL B: Job Destruction } \\
\hline \multirow[t]{2}{*}{ TRER $_{\mathrm{kt}} *$ Enforcement $_{\mathrm{mt}}$} & -0.003 & -0.001 & $-0.039 * *$ \\
\hline & $(0.013)$ & $(0.016)$ & $(0.018)$ \\
\hline \multirow{3}{*}{ Trade-weighted $\mathrm{RER}_{\mathrm{kt}}$} & $0.101^{*}$ & $0.146^{* *}$ & 0.115 \\
\hline & $(0.053)$ & $(0.069)$ & $(0.073)$ \\
\hline & \multicolumn{3}{|c|}{ PANEL C: Log (Hours) } \\
\hline \multirow[t]{2}{*}{ TRER $_{\mathrm{kt}} *$ Enforcement $_{\mathrm{mt}}$} & 0.003 & -0.001 & 0.007 \\
\hline & $(0.003)$ & $(0.003)$ & $(0.005)$ \\
\hline \multirow{3}{*}{ Trade-weighted $\mathrm{RER}_{\mathrm{kt}}$} & -0.012 & -0.002 & -0.018 \\
\hline & $(0.015)$ & $(0.022)$ & $(0.022)$ \\
\hline & \multicolumn{3}{|c|}{ PANEL D: Full-Time Contract } \\
\hline \multirow[t]{2}{*}{ TRER $_{\mathrm{kt}}{ }^{*}$ Enforcement ${ }_{\mathrm{mt}}$} & 0.002 & -0.006 & $0.012^{*}$ \\
\hline & $(0.007)$ & $(0.011)$ & $(0.007)$ \\
\hline \multirow{2}{*}{ Trade-weighted $\mathrm{RER}_{\mathrm{kt}}$} & 0.010 & 0.018 & -0.009 \\
\hline & $(0.018)$ & $(0.022)$ & $(0.027)$ \\
\hline Number of Obs. & 322,614 & 169,890 & 152,724 \\
\hline City-Year Controls & YES & YES & YES \\
\hline Worker-Year Controls & YES & YES & YES \\
\hline Plant-Year Controls & YES & YES & YES \\
\hline Sector-Year Controls & YES & YES & YES \\
\hline State-Year Dummies & YES & YES & YES \\
\hline Match Fixed Effects & YES & YES & YES \\
\hline
\end{tabular}

Source: Authors' calculations based on RAIS, Ministry of Labor administrative data on inspections, IMF bilateral real exchange rates, NBER trade flows, and SECEX (1996-2001) and IPEA @Cidades (1991-1996).

Note: This table reports coefficients from the ordinary least squares estimation of equation (4) in the paper, where the dependent variable in Panel A is an indicator variable which takes the value one if a match between worker $i$ and plant $\mathrm{j}$ is created in time $t$, the dependent variable in Panel B is an indicator variable which takes the value one if a match between worker $i$ and plant $j$ is destroyed in time $t$, the dependent variable in Panel C is the logarithm of hours worked for worker $i$ employed at plant $j$ in time $t$, and the dependent variable in Panel D is an indicator variable which takes the value one if worker $i$ is employed in plant $j$ at time $t$ with a full-time contract, for all plants and by the plant's export status. ${ }^{* * *}$ denotes significance at the $1 \%$ level; ${ }^{* *}$ denotes significance at the $5 \%$ level; ${ }^{*}$ denotes significance at the $10 \%$ level. Robust standard errors, clustered at the city-industry level, are reported in parentheses. Enforcement is measured as the logarithm of the number of inspections in the city (plus one) per 100 plants in the city. Unreported covariates at the city-level include enforcement and initial city conditions (industrial composition, population, urbanization, and poverty rates) interacted with the trade-weighted real exchange rate. Unreported covariates at the worker level include the worker's age (and age squared), tenure at the plant in months, education (as two dummy variables-at least high school and more than high school where less than high school is the omitted category) and occupation (as three dummy variables-skilled blue collar worker, unskilled white collar worker, and professional/managerial worker where unskilled blue collar worker is the omitted category). At the plant level, we include average plant wages, plant employment, average worker tenure at the plant, and the age, gender, educational, and occupational composition of the plant. We also include the following industry characteristics: the industry unionization rate, industry employment, average worker tenure in the industry, and the age, gender, educational, and occupational composition of the industry. 
Table 5.2: Trade, Lagged Enforcement, and Labor Adjustment

\begin{tabular}{lccc}
\hline \hline & All & Exporters & Non-Exporters \\
\hline & \multicolumn{3}{c}{ PANEL A: Job Creation } \\
TRER $_{\text {kt }}{ }^{*}$ Enforcement $_{\mathrm{mt}-1}$ & 0.004 & -0.002 & 0.014 \\
Trade-weighted RER $_{\mathrm{kt}}$ & $(0.006)$ & $(0.007)$ & $(0.010)$ \\
& -0.023 & -0.032 & -0.016 \\
& $(0.026)$ & $(0.030)$ & $(0.046)$ \\
TRER $_{\mathrm{kt}}{ }^{*}$ Enforcement & PANEL B: Job Destruction \\
& $-0.020^{*}$ & -0.015 & $-0.042^{* *}$ \\
Trade-weighted RER $_{\mathrm{kt}}$ & $(0.012)$ & $(0.015)$ & $(0.020)$ \\
& -0.014 & 0.040 & -0.047 \\
Number of Obs. $_{\text {City-Year Controls }}$ & $0.061)$ & $(0.080)$ & $(0.087)$ \\
Worker-Year Controls & 170,169 & 96,428 & 73,741 \\
Plant-Year Controls & YES & YES & YES \\
Sector-Year Controls & YES & YES & YES \\
State-Year Dummies & YES & YES & YES \\
Match Fixed Effects & YES & YES & YES \\
\hline \hline
\end{tabular}

Source: Authors' calculations based on RAIS, Ministry of Labor administrative data on inspections, IMF bilateral real exchange rates, NBER trade flows, and SECEX (1996-2001) and IPEA @Cidades (1991-1996).

Note: This table reports coefficients from the ordinary least squares estimation of equation (4) in the paper, where the dependent variable in Panel A is an indicator variable which takes the value one if a match between worker $i$ and plant $j$ is created in time $t$ and the dependent variable in Panel B is an indicator variable which takes the value one if a match between worker $i$ and plant $j$ is destroyed in time $t$, for all plants and by the plant's export status. *** denotes significance at the $1 \%$ level; ${ }^{* *}$ denotes significance at the $5 \%$ level; * denotes significance at the $10 \%$ level. Robust standard errors, clustered at the city-industry level, are reported in parentheses. Enforcement is measured as the lagged value of the logarithm of the number of inspections in the city (plus one) per 100 plants in the city. Unreported covariates at the city-level include lagged enforcement and initial city conditions (industrial composition, population, urbanization, and poverty rates) interacted with the trade-weighted real exchange rate. Unreported covariates at the worker level include the worker's age (and age squared), tenure at the plant in months, education (as two dummy variables-at least high school and more than high school where less than high school is the omitted category) and occupation (as three dummy variables - skilled blue collar worker, unskilled white collar worker, and professional/managerial worker where unskilled blue collar worker is the omitted category). At the plant level, we include average plant wages, plant employment, average worker tenure at the plant, and the age, gender, educational, and occupational composition of the plant. We also include the following industry characteristics: the industry unionization rate, industry employment, average worker tenure in the industry, and the age, gender, educational, and occupational composition of the industry. 
Table 5.3: Trade, Enforcement, and Labor Adjustment, First-Difference

\begin{tabular}{|c|c|c|c|}
\hline & All & Exporters & Non-Exporters \\
\hline & \multicolumn{3}{|c|}{ PANEL A: Job Creation } \\
\hline \multirow[t]{2}{*}{$\Delta \mathrm{TRER}_{\mathrm{kt}}{ }^{*}$ Enforcement $_{\mathrm{mt}}$} & -0.017 & -0.024 & $0.051^{* *}$ \\
\hline & $(0.017)$ & $(0.023)$ & $(0.022)$ \\
\hline \multirow{2}{*}{$\Delta$ Trade-weighted $\mathrm{RER}_{\mathrm{kt}}$} & 0.045 & -0.146 & 0.164 \\
\hline & $(0.079)$ & $(0.104)$ & $(0.101)$ \\
\hline & \multicolumn{3}{|c|}{ PANEL B: Job Destruction } \\
\hline \multirow[t]{2}{*}{$\Delta \mathrm{TRER}_{\mathrm{kt}}{ }^{*}$ Enforcement $_{\mathrm{mt}}$} & -0.005 & 0.011 & $-0.048^{* *}$ \\
\hline & $(0.015)$ & $(0.019)$ & $(0.021)$ \\
\hline \multirow{2}{*}{$\Delta$ Trade-weighted $\mathrm{RER}_{\mathrm{kt}}$} & $0.159 * *$ & 0.115 & $0.267^{* * *}$ \\
\hline & $(0.063)$ & $(0.083)$ & $(0.088)$ \\
\hline Number of Obs. & 169,264 & 96,098 & 73,166 \\
\hline City-Year Controls & YES & YES & YES \\
\hline Worker-Year Controls & YES & YES & YES \\
\hline Plant-Year Controls & YES & YES & YES \\
\hline Sector-Year Controls & YES & YES & YES \\
\hline State-Year Dummies & YES & YES & YES \\
\hline Match Fixed Effects & YES & YES & YES \\
\hline
\end{tabular}

Source: Authors' calculations based on RAIS, Ministry of Labor administrative data on inspections, IMF bilateral real exchange rates, NBER trade flows, and SECEX (1996-2001) and IPEA @Cidades (1991-1996).

Note: This table reports coefficients from the ordinary least squares estimation of equation (4) in the paper in first differences, where the dependent variable in Panel A is an indicator variable which takes the value one if a match between worker $i$ and plant $j$ is created in time $t$ and the dependent variable in Panel B is an indicator variable which takes the value one if a match between worker $i$ and plant $j$ is destroyed in time $t$, for all plants and by the plant's export status. ${ }^{* * *}$ denotes significance at the $1 \%$ level; ${ }^{* *}$ denotes significance at the $5 \%$ level; ${ }^{*}$ denotes significance at the $10 \%$ level. Robust standard errors, clustered at the city-industry level, are reported in parentheses. Enforcement is measured as the logarithm of the number of inspections in the city (plus one) per 100 plants in the city. Unreported covariates at the city-level include enforcement and initial city conditions (industrial composition, population, urbanization, and poverty rates) interacted with the trade-weighted real exchange rate. Unreported covariates at the worker level include the worker's age (and age squared), tenure at the plant in months, education (as two dummy variables-at least high school and more than high school where less than high school is the omitted category) and occupation (as three dummy variables—skilled blue collar worker, unskilled white collar worker, and professional/managerial worker where unskilled blue collar worker is the omitted category). At the plant level, we include average plant wages, plant employment, average worker tenure at the plant, and the age, gender, educational, and occupational composition of the plant. We also include the following industry characteristics: the industry unionization rate, industry employment, average worker tenure in the industry, and the age, gender, educational, and occupational composition of the industry. 
Table 5.4: Trade, Enforcement, and Labor Adjustment, By Sector Tech-Intensity

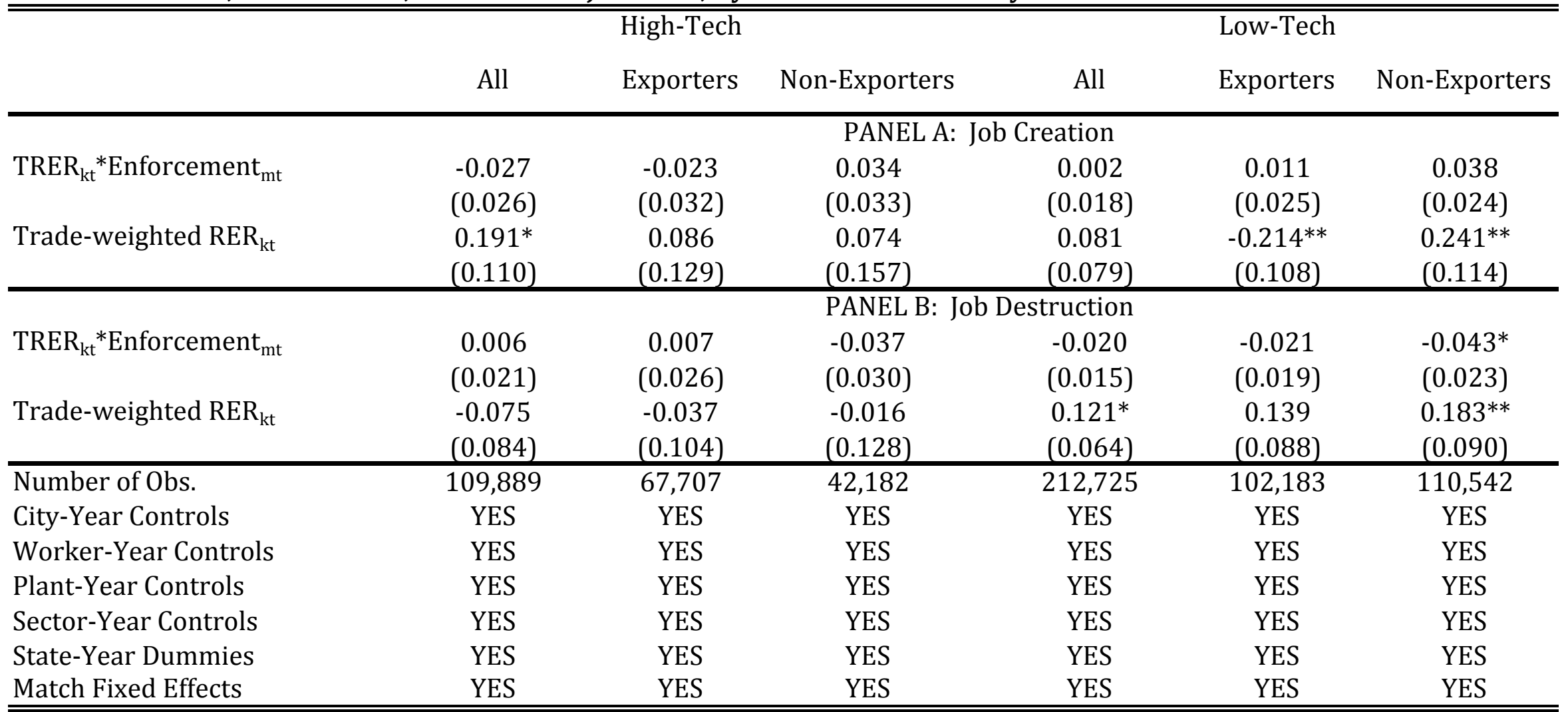

Source: Authors' calculations based on RAIS, Ministry of Labor administrative data on inspections, IMF bilateral real exchange rates, NBER trade flows, and SECEX (1996-2001), IPEA@Cidades (19911996), and World Bank Investment Climate Assessment Reports.

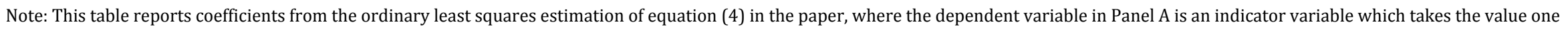
if a match between worker $i$ and plant $j$ is created in time $t$ and the dependent variable in Panel B is an indicator variable which takes the value one if a match between workeri and plant $j$ is destroyed in time $t$, by the sector's tech-intensity and export status. ${ }^{* *}$ denotes significance at the $1 \%$ level; ** denotes significance at the $5 \%$ level; ${ }^{*}$ denotes significance at the $10 \%$ level. Robust standard errors, clustered at the city-industry level, are reported in parentheses. Enforcement is measured as the logarithm of the number of inspections in the city (plus one) per 100 plants in the city. Unreported covariates at the city-level include enforcement and initial city conditions (industrial composition, population, urbanization, and poverty rates) interacted with the trade-weighted real exchange rate. Unreported covariates at the worker level include the worker's age (and age squared), tenure at the plant in months, education (as two dummy variables-at least high school and more than high school where less than high school is the omitted category) and occupation (as three dummy variables-skilled blue collar worker, unskilled white collar worker, and

professional/managerial worker where unskilled blue collar worker is the omitted category). At the plant level, we include average plant wages, plant employment, average worker tenure at the

plant, and the age, gender, educational, and occupational composition of the plant. We also include the following industry characteristics: the industry unionization rate, industry employment, average worker tenure in the industry, and the age, gender, educational, and occupational composition of the industry. 
Table 5.5: Trade, Enforcement, and Labor Adjustment, By Plant Size

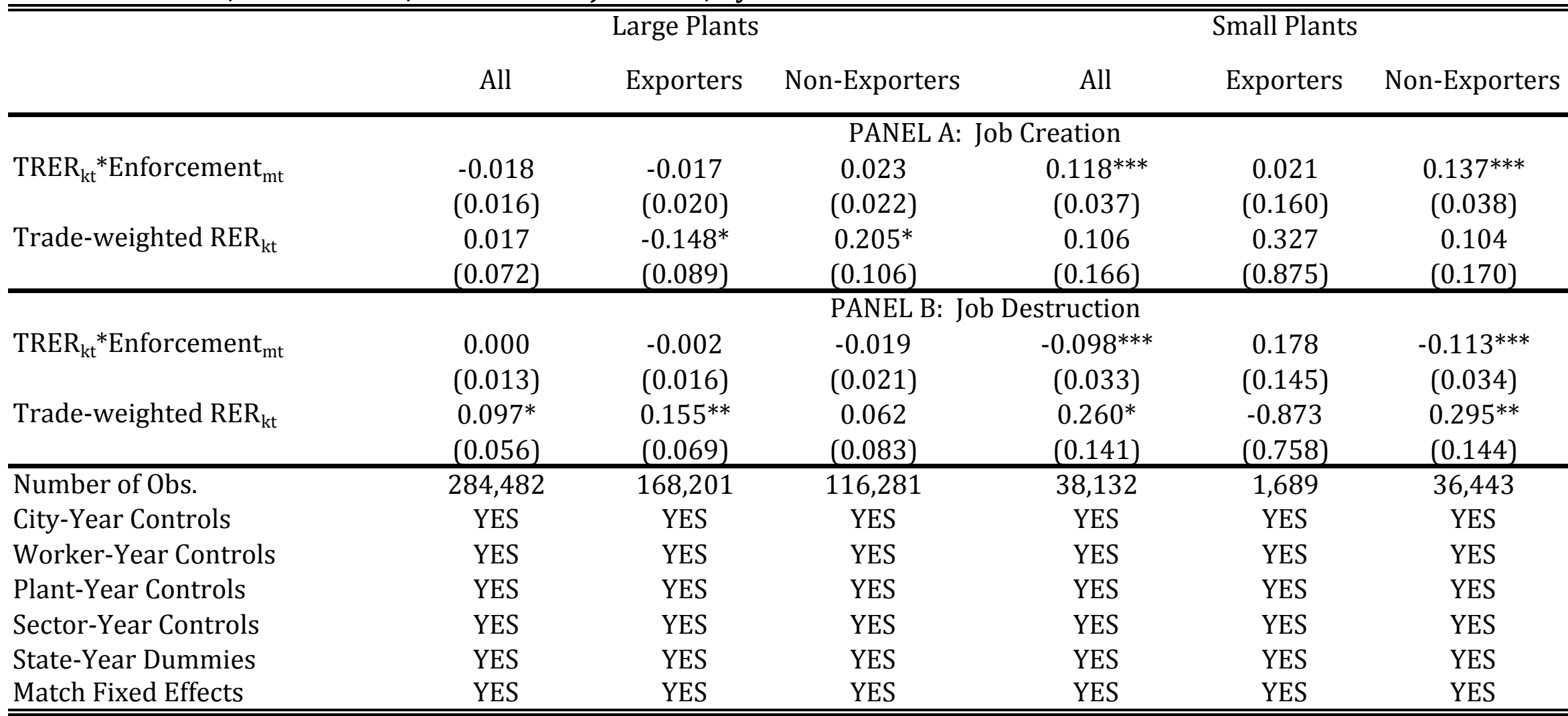

Source: Authors' calculations based on RAIS, Ministry of Labor administrative data on inspections, IMF bilateral real exchange rates, NBER trade flows, and SECEX (1996-2001) and IPEA@Cidades (1991-1996)

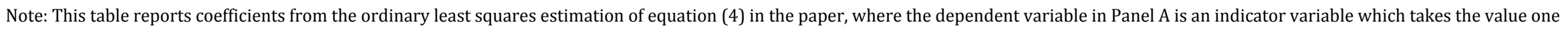
if a match between worker $i$ and plant $j$ is created in time $t$ and the dependent variable in Panel B is an indicator variable which takes the value one if a match between workeri and plant $j$ is destroyed in time $t$, by the plant's size and export status. ${ }^{* * *}$ denotes significance at the $1 \%$ level; ** denotes significance at the $5 \%$ level; * denotes significance at the $10 \%$ level. Robust standard errors, clustered at the city-industry level, are reported in parentheses. Enforcement is measured as the logarithm of the number of inspections in the city (plus one) per 100 plants in the city. Unreported covariates at the city-level include enforcement and initial city conditions (industrial composition, population, urbanization, and poverty rates) interacted with the trade-weighted real exchange rate. Unreported covariates at the worker level include the worker's age (and age squared), tenure at the plant in months, education (as two dummy variables-at least high school and more than high school where less than high school is the omitted category) and occupation (as three dummy variables-skilled blue collar worker, unskilled white collar worker, and professional/managerial worker where unskilled blue collar worker is the omitted category). At the plant level, we include average plant wages, plant employment, average worker tenure at the plant, and the age, gender, educational, and occupational composition of the plant. We also include the following industry characteristics: the industry unionization rate, industry employment, average worker tenure in the industry, and the age, gender, educational, and occupational composition of the industry. 
Table 5.6: Trade, Enforcement, and Labor Adjustment, By Worker Age

Older Workers

Younger Workers

All

Exporters Non-Exporters

All

Exporters Non-Exporters

\begin{tabular}{|c|c|c|c|c|c|c|}
\hline \multirow{3}{*}{ TRER $_{\mathrm{kt}}{ }^{*}$ Enforcement ${ }_{\mathrm{mt}}$} & \multicolumn{6}{|c|}{ PANEL A: Job Creation } \\
\hline & -0.021 & -0.002 & 0.021 & -0.006 & -0.010 & $0.050^{*}$ \\
\hline & $(0.016)$ & $(0.020)$ & $(0.024)$ & $(0.021)$ & $(0.030)$ & $(0.028)$ \\
\hline \multirow[t]{2}{*}{ Trade-weighted RER $\mathrm{kt}_{\mathrm{k}}$} & 0.056 & -0.124 & $0.268 * * *$ & 0.045 & -0.185 & 0.114 \\
\hline & $(0.070)$ & $(0.084)$ & $(0.102)$ & $(0.100)$ & $(0.138)$ & $(0.138)$ \\
\hline & \multicolumn{6}{|c|}{ PANEL B: Job Destruction } \\
\hline \multirow{2}{*}{ TRER $_{\mathrm{kt}} *$ Enforcement $_{\mathrm{mt}}$} & -0.005 & -0.003 & -0.031 & -0.014 & -0.009 & $-0.056^{* *}$ \\
\hline & $(0.014)$ & $(0.018)$ & $(0.023)$ & $(0.018)$ & $(0.023)$ & $(0.026)$ \\
\hline \multirow[t]{2}{*}{ Trade-weighted $\mathrm{RER}_{\mathrm{kt}}$} & 0.082 & $0.119 *$ & 0.058 & 0.107 & 0.165 & 0.159 \\
\hline & $(0.059)$ & $(0.072)$ & $(0.091)$ & $(0.079)$ & $(0.109)$ & $(0.108)$ \\
\hline Number of Obs. & 158,447 & 87,998 & 70,449 & 164,167 & 81,892 & 82,275 \\
\hline City-Year Controls & YES & YES & YES & YES & YES & YES \\
\hline Worker-Year Controls & YES & YES & YES & YES & YES & YES \\
\hline Plant-Year Controls & YES & YES & YES & YES & YES & YES \\
\hline Sector-Year Controls & YES & YES & YES & YES & YES & YES \\
\hline State-Year Dummies & YES & YES & YES & YES & YES & YES \\
\hline Match Fixed Effects & YES & YES & YES & YES & YES & YES \\
\hline
\end{tabular}

Source: Authors' calculations based on RAIS, Ministry of Labor administrative data on inspections, IMF bilateral real exchange rates, NBER trade flows, and SECEX (1996-2001) and IPEA@Cidades (1991-1996)

Note: This table reports coefficients from the ordinary least squares estimation of equation (4) in the paper, where the dependent variable in Panel A is an indicator variable which takes the value one if a match between worker $i$ and plant $j$ is created in time $t$ and the dependent variable in Panel B is an indicator variable which takes the value one if a match between workeri and plant $j$ is destroyed in time $t$, by the worker's age and export status. ${ }^{* * *}$ denotes significance at the $1 \%$ level; ${ }^{* *}$ denotes significance at the $5 \%$ level; * denotes significance at the $10 \%$ level. Robust standard errors, clustered at the city-industry level, are reported in parentheses. Enforcement is measured as the logarithm of the number of inspections in the city (plus one) per 100 plants in the city. Unreported covariates at the city-level include enforcement and initial city conditions (industrial composition, population, urbanization, and poverty rates) interacted with the trade-weighted real exchange rate. Unreported covariates at the worker level include the worker's age (and age squared), tenure at the plant in months, education (as two dummy variables-at least high school and more than high school where less than high school is the omitted category) and occupation (as three dummy variables-skilled blue collar worker, unskilled white collar worker, and professional/managerial worker where unskilled blue collar worker is the omitted category). At the plant level, we include average plant wages, plant employment, average worker tenure at the plant, and the age, gender, educational, and occupational composition of the plant. We also include the following industry characteristics: the industry unionization rate, industry employment, average worker tenure in the industry, and the age, gender, educational, and occupational composition of the industry. 
Table 5.7: Trade, Enforcement, and Plant-Level Wages

\begin{tabular}{lccc}
\hline \hline $\begin{array}{l}\text { Dep. Variable: } \\
\text { Log (Average Wage) }{ }_{\mathrm{jmkt}}\end{array}$ & All & Exporters & Non-Exporters \\
\hline TRER $_{\mathrm{kt}}^{*}$ Enforcement $_{\mathrm{mt}}$ & $0.029^{*}$ & -0.004 & $0.037^{* *}$ \\
& $(0.016)$ & $(0.031)$ & $(0.018)$ \\
Trade-weighted RER & & -0.140 & $-0.131^{* *}$ \\
& $-0.130^{* *}$ & $(0.146)$ & $(0.064)$ \\
\hline Number of Obs. & $(0.063)$ & 70,128 & 199,294 \\
Plant-Year Controls & Y69,422 & YES & YES \\
Sector-Year Controls & YES & YES & YES \\
State-Year Dummies & YES & YES & YES \\
Plant Fixed Effects & YES & YES & YES \\
\hline \hline
\end{tabular}

Source: Authors' calculations based on RAIS, administrative data from the Brazilian Ministry of Labor, IMF bilateral real exchange rates, NBER trade flows, and SECEX (1996-2001).

Note: This table reports coefficients from the ordinary least squares estimation of equation (2) in the paper, where the dependent variable is the logarithm of plant-level average wages. Enforcement is measured as the logarithm of the number of inspections in the city (plus one) per 100 plants in the city. ${ }^{* * *}$ denotes significance at the $1 \%$ level; ${ }^{* *}$ denotes significance at the $5 \%$ level; ${ }^{*}$ denotes significance at the $10 \%$ level. Robust standard errors, clustered at the city-industry level, are reported in parentheses. All regressions also include city-level enforcement. Unreported covariates at the plantlevel include average worker tenure at the plant, the age, gender, educational, and occupational composition of the plant. Unreported industry-level covariates include the unionization rate, industry employment, average worker tenure in the industry, and the age, gender, educational, and occupational composition of the industry. 